Chapter 5

\title{
The Use of Acute Phase Proteins as Biomarkers of Diseases in Cattle and Swine
}

\author{
Csilla Tóthová, Oskar Nagy and Gabriel Kováč \\ Additional information is available at the end of the chapter \\ http://dx.doi.org/10.5772/55857
}

\section{Introduction}

The acute phase response is a nonspecific and complex reaction of an organism that occurs shortly after any tissue injury. The origin of this response can be attributable to infectious, traumatic, immunologic, neoplastic, or other causes, in order to restore homeostasis, reduce tissue damage, and to remove the cause of disturbances [1]. The acute phase response is characterized by a number of different systemic effects, a range of metabolic activities and alterations in a wide variety of biochemical processes. One of the most important metabolic changes is the strongly increased (or decreased) production and secretion of some plasma proteins from the liver, the acute phase proteins [2]. The acute phase response is a very fast response, developing with increased concentrations of acute phase proteins within a few hours, which remain elevated as long as the inflammatory stimulus persists [3]. For this reason, they represent the ideal tool for the early identification of inflammation or injury, and for monitoring the outcome of disease processes. Unfortunately, acute phase proteins are poorly specific, since they increase in the presence of inflammation independent of the agent responsible, but the increase in their concentrations indicates that "something" is happening in the body, and should lead clinician to investigate the site, type and severity of the inflammation (complete clinico-pathological approach), to identify the pathogen responsible (specific diagnostic methods), and to follow-up the treatment.

Acute phase proteins have been studied widely in human medicine, especially as biomarkers of diseases, inflammatory processes and various infections, to diagnose and monitor the success of diseases in clinical praxis [4,5]. However, they have been relatively under-utilised in the veterinary medicine, and the possible influence of inflammatory conditions on the concentrations of these proteins, and they use as indicators in the monitoring of animal health and detection of diseases in veterinary clinical practice, especially in farm animal medicine is 
less well documented. For this reason, the main purpose of this article is to provide an integrated overview about the diagnostically valuable acute phase proteins in farm animals, to update the knowledge about their usefulness in the detection and diagnosis of various economically important diseases of ruminants and swine, and present some new knowledge regarding their clinical applicability and methods for determination.

\section{The acute phase response}

The acute phase response is a complex early-defense system induced by any process that leads to tissue damage, e.g. bacterial and viral infection, inflammation, parasite infestation, trauma, surgery, ischemic necrosis, burns, neoplastic growth [6]. The reactions of the acute phase response are part of the non-specific immune system and thus the first line of defense against invading pathogens, which is responsible for the survival of the host during the critical early stages of the attack. It is designed to hold the infection in check until the adaptive, highly specialized immune response is initiated [7]. The acute phase response is a cascade of host responses with the goal of reestablishing the homeostasis, to remove the cause of disturbance and promote the healing process [8].

The pathogenesis of the acute phase response begins within inflammatory sites, where cells involved in the innate immune response (i.e. macrophages, monocytes) produce and release a vast number of inflammatory mediators, among which the cytokines (such as interleukin-1, interleukin- 6 and tumor necrosis factor- $\alpha$ ) play very important roles [9]. These cytokines influence organs involved in homeostasis, such as the central nervous system (CNS), the autonomic nervous system and the adrenal gland, to establish a rapid and intense protective or reactive response [10]. Cytokines induce a cascade of events which potentiate the appearance of the main clinical changes charecterized by fever, anorexia or weight loss [11]. In addition, the cytokines activate receptors on different target cells leading to systemic inflammatory reactions, including hormonal or metabolic, and resulting in a number of biochemical changes [12]. These symptoms reflect multiple changes in the homeostatic control of the diseased animals, such as increased production of adrenocorticotrophic hormone and glucocorticoids, activation of the complement cascade and blood coagulation system, decreased serum concentrations of calcium, zinc, iron, vitamin A and $\alpha$-tocopherol, and changes in the concentrations of some plasma proteins [13]. One of the most important metabolic changes is the strongly increased synthesis of a group of plasma proteins, namely acute phase proteins, by the liver [14].

\section{Acute phase proteins}

In general, the acute phase proteins are a group of blood proteins that change in concentrations in animals subjected to external or internal challenges, such as infection, inflammation, trauma or stress [1]. Acute phase proteins can be classified according to the magnitude of the increase 
(positive acute phase proteins) or decrease (negative acute phase proteins) in their serum concentrations during the acute phase response [15]. They are further classified as major, moderate, or minor, depending on their responsibility. Major proteins represent those that increase 10- to 100-fold, moderate proteins increase 2- to 10-fold, and minor proteins are characterized with only a slight increase [16]. Major proteins often are observed to increase markedly within the first $24-48$ hours after the triggering event and often have a rapid decline due to their very short half-life. Moderate and minor proteins follow in magnitude of response and may both increase more slowly and be more prolonged in duration, depending on the status of the triggering event [17]. Moderate and minor acute phase proteins may be observed more often during chronic inflammatory processes [18]. In these cases, an aberrant continuation of some aspects of the acute phase response may contribute to the underlying tissue damage, which accompanies the disease and also may lead to further complications, for example protein deposition such as reactive amyloidosis [19].

Generally, the main function of acute phase proteins is to defend the host against pathological damage and assist in the restoration of the homeostasis. Some of the acute phase proteins $\left(\alpha_{1^{-}}\right.$ antitrypsin, $\alpha_{2}$-macroglobulin) have anti-protease activity designed to inhibit proteases released by phagocytes or pathogens to minimize damage to normal tissues [13]. Another acute phase proteins (haptoglobin, serum amyloid A, C-reactive protein) have scavenging activities and bind metabolites released from cellular degradation so they can re-enter host metabolic processes rather than be utilized by pathogen [20]. Others ( $\alpha_{1}$-acid glycoprotein) are characterized by anti-bacterial activity and by the ability to influence the course of the immune response [21].

Despite the uniform nature of the acute phase response, there are numerous differences in the acute phase characteristics between different animal species [13]. The important concept is that each animal species has its own major acute phase proteins that must be considered the markers of choice for diagnostic purposes. Ruminants are significantly different to other species in their acute phase response, in that haptoglobin (Hp) and serum amyloid A (SAA) are the major acute phase proteins [22]. On the other hand, in pigs, significant increases of Creactive protein have been detected after an inflammatory stimulus [23].

\section{The diagnostic utility of acute phase proteins in the veterinary practice}

It is important to recognize that acute phase protein concentrations are elevated in animals with many different diseases, having very poor diagnostic specificity in detecting the cause, so they can not be used as the primary diagnostic test for a particular disease. However, they have very high sensitivity in detecting many conditions that alter the health of the animal and in providing evidence that an animal has subclinical inflammation or infection [16]. It was reported by Kent [24] that acute phase proteins quickly and precisely demonstrate the presence of infectiousand inflammatory conditions, butnot the cause. A very interesting characteristic of theacute phase proteins is the possibility of detecting subclinical diseases [16]. Petersen et al. [15] stated also that acute phase proteins can detect the presence of subclinical disease which is the cause of 
reduced growth rate and losses in the production. In the clinical field, acute phase proteins may serve as indicators of prognosis and effect of treatment. The magnitude and duration of the acute phase response reflect the severity of the infection and underlying tissue damage [25]

Practical uses and advantages of acute phase protein assays in small animals have been described and demonstrated in a large number of scientific reports published in a last few years. However, clinical application of acute phase proteins in large animals has not been sufficiently standardized in routine practice. The possible use of acute phase proteins in ruminants and swine has been investigated in various inflammatory and non-inflammatory conditions. However, there are many more areas of enquiry which can be pursued to deepen our knowledge about the acute phase response and also to develop novel applications for the acute phase proteins, e.g. during some less frequently studied diseases of young (diarrhoea, omphalophlebitis) and adult cattle (laminitis, mastitis), as well as not only in acute infections, but also in chronic inflammatory conditions. Moreover, the concentrations of acute phase proteins must be interpreted in the view of many other influences not associated with diseases. The age of evaluated animals, parturition, the transition of pregnancy to lactation are important factors that may affect the concentrations of frequently analyzed biochemical variables, including the concentrations of acute phase proteins. Considering that the evaluation of acute phase proteins would be important diagnostic aid available to clinicians, their usefulness for diagnosis and prognosis of various disorders and diseases in cattle and swine will be discussed, including the influence of some physiologic conditions on their values.

\subsection{The effect of age on the concentrations of acute phase proteins}

After birth, newborns and young animals go through a period of rapid growth and development, and adapt to life outside the uterus. This transition from foetal to neonatal life and then from newborn to young animal necessitates major physiological adjustments [26]. Young calves must adapt to various environmental factors, including nutrition which changes from a primarily carbohydrate-based energy supply during the foetal period to a high fat and relatively low carbohydrate nutritional energy supply in colostrum and milk, and then from milk to solid diet [27]. The exposure to the new environment and foreign antigens requires the establishment of appropriate defence responses [28]. The neonate is immunocompetent, but the adaptive immune system is immature [29]. Non-specific defence mechanisms, including the reactions of the acute phase response may thus be important for the adaptation to complicated physiological processes during growth and development of calves. Therefore, the concentrations of acute phase proteins may be influenced by the age of evaluated animals. The concentrations measured in young calves thus may differ from the values in adult cattle. Therefore, higher concentrations of acute phase proteins, which in adult cattle may indicate an inflammatory process, in young calves are not necessarily a sign of the activation of the acute phase protein production by some inflammatory stimulus, or a sign of a disease.

Possible factors affecting the concentrations of acute phase proteins after birth include foetal synthesis of acute phase proteins, the stimulation of their production by birth trauma, intake of colostrum containing acute phase proteins or their stimulants, and immaturity of synthesis 


\begin{tabular}{|c|c|c|c|c|c|c|c|c|}
\hline \multirow[t]{2}{*}{ Variable } & & \multicolumn{6}{|c|}{ Age of the calves (months) } & \multirow[t]{2}{*}{$\mathbf{P}$} \\
\hline & & 1 & 2 & 3 & 4 & 5 & 6 & \\
\hline \multirow[t]{2}{*}{$\mathrm{Hp}(\mathrm{mg} / \mathrm{ml})$} & $x$ & $0.068^{A}$ & 0.064 & 0.056 & 0.213 & 0.062 & $0.021^{\mathrm{A}}$ & $<0.05$ \\
\hline & $\pm S D$ & 0.021 & 0.026 & 0.024 & 0.344 & 0.081 & 0.018 & \\
\hline \multirow[t]{2}{*}{ SAA $(\mu \mathrm{g} / \mathrm{ml})$} & $x$ & $59.12^{\mathrm{a}}$ & 53.37 & 39.71 & 21.20 & $10.51^{\mathrm{a}}$ & 19.86 & $<0.05$ \\
\hline & $\pm S D$ & 35.61 & 21.43 & 26.65 & 19.97 & 10.36 & 27.42 & \\
\hline \multirow[t]{2}{*}{$\operatorname{Fbg}(g / l)$} & $x$ & 2.31 & $3.14^{a}$ & 2.55 & 2.87 & $2.82^{b}$ & $2.17^{a, b}$ & $<0.01$ \\
\hline & $\pm S D$ & 0.76 & 0.75 & 0.32 & 0.57 & 0.40 & 0.20 & \\
\hline
\end{tabular}

The same superscripts in rows mean statistical significance of differences in concentrations between the columns: $a, b-$ $P<0.05, A-P<0.01$

$\mathrm{P}$ - significance of the differences

Table 1. Age-related changes in the concentrations of evaluated acute phase proteins in clinically healthy calves from the 1 st till 6 th month of age [34]

capacity of the newborn liver [28]. Introduction to the extrauterine environment, which contains various microbes, could also trigger an inflammatory response. Colostrum contains high amount of inflammatory mediators such as cytokines, which may induce the acute phase response in newborns. Transfer of colostral cytokines to the blood of calves has been reported by Yamanaka et al. [30]. In addition, direct transfer of some acute phase proteins from colostrum to newborns may potentially occur. Schroedl et al. [31] found elevated concentrations of CRP in young calves. They concluded that although CRP in cattle is not a major acute phase protein, bovine colostrum contains high amounts of CRP and its transfer contributes to elevated concentrations in newborn calves. Moreover, high concentrations of mammaryassociated SAA in the colostrum of healthy cows were found, which have a primarily protective effect on the gastrointestinal tract of neonates by stimulating mucin production and reducing adherence of pathogens [32]. Immaturity of the neonatal liver to mount an acute phase response to an inflammatory stimulus could affect the concentrations of acute phase proteins in neonatal animals. For example, low Hp concentrations are common in newborn infants, which are related to the immaturity of the liver to produce $\mathrm{Hp}$ in a situation where Hp consumption is increased because of haemolysis of foetal erythrocytes [33].

Tóthová et al. [34] evaluated the age-dependent changes in the concentrations of haptoglobin (Hp), serum amyloid A (SAA) and fibrinogen (Fbg) in clinically healthy calves during the first 6 month of life. The most pronounced changes they observed in the concentrations of SAA, with the highest concentrations at the age of 1 month followed by gradually decreasing values to 5th month of life (Table 1). Orro et al. [28] reported also higher mean serum concentrations of SAA shortly after birth, being the highest at the age of 7 days $(112.0 \mathrm{mg} / \mathrm{l})$, and decreased after 10 days of age. In contrast, low SAA concentrations have been noted by Alsemgeest et al. [35] in calves sampled within 10 min after parturition. The results obtained by Tóthová et al. [34] showed in calves less pronounced changes in the Hp concentrations during the first three 
months of life than those observed in the serum SAA concentrations. The concentrations of $\mathrm{Hp}$ in the blood serum of calves in the first three months after birth were roughly uniform, and the values were comparable with the concentrations measured in healthy adult cattle. Similar findings were reported by Hyvönen et al. [36]. Orro et al. [28] also stated that serum Hp concentrations after birth were more stable compared with serum amyloid A. Slightly higher mean Hp concentration was observed by the abovementioned authors at the age of 3 days, and then (after a small decrease) the serum concentrations of Hp remained relatively stabile. Schroedl et al. [31] described that the concentrations of $\mathrm{Hp}$ in newborn calves did not differ between samples obtained at birth, at 1 day of age and at 10 days of age. Studies performed by Knowles et al. [37] showed that the concentrations of fibrinogen in calves increased during the first 2 weeks after birth, although the rise was relatively small, and the concentrations did not exceed the general reference limit used for healthy cattle. Very similar transient and relatively small increases in Fbg concentrations during the first 2 weeks of life in calves have been reported by Gentry et al. [38]. The results presented by Tóthová et al. [34] showed a transient increase in the plasma concentrations of fibrinogen at the age of 2 months, which was followed by a repeated decrease of Fbg concentrations, and the obtained values were similar to those usually measured in healthy adult cattle.

\section{Acute phase proteins in cattle}

\subsection{Haptoglobin}

Haptoglobin (Hp) is a glycoprotein composed of $2 \alpha$ and $2 \beta$ subunits. The $\alpha$ subunit has a molecular weight of $16-23 \mathrm{kDa}$ and the $\beta$ subunit $35-40 \mathrm{kDa}$. The subunits combine in the form of a $\beta-\alpha-\alpha-\beta$ tetramer chain [39]. In the circulation, Hp is highly polymerized having a molecular weight of approximately $1000-2000 \mathrm{kDa}$, and exists also as polymer associated with albumin [40]. The primary function of $\mathrm{Hp}$ is to bind free hemoglobin in the blood. By removing from the circulation any free hemoglobin, which has inherent peroxidase activity, Hp prevents oxidative damage to tissues [41]. The Hp-hemoglobin binding also reduces the availability of the heme residue from bacterial growth and therefore Hp has an indirect antibacterial activity [1]. Many studies have indicated the significance of $\mathrm{Hp}$ as a clinically useful parameter for measuring the occurrence and severity of inflammatory responses in cattle with mastitis, pneumonia, enteritis, peritonitis, endocarditis, abscesses, endometritis and other natural or experimental infectious conditions [42].

Assays for serum Hp concentration include spectrophotometric methods and immunoassays. The spectrophotometric assays are based on the ability of $\mathrm{Hp}$ to bind hemoglobin $(\mathrm{Hb})$, forming $\mathrm{Hp}-\mathrm{Hb}$ complexes that either alter the absorbance characteristic for $\mathrm{Hb}$ in proportion to the concentration of $\mathrm{Hp}$ in a serum sample, or preserve peroxidase activity at an acidic $\mathrm{pH}$, which then can be detected and quantified [43]. In addition, an automated spectrophotometric multispecies assay based on this reactivity has been developed [44]. Nephelometric immunoassays, in which the rate of the precipitation of the antibody-antigen complex is measured, have been validated for the estimation of Hp [45]. 


\subsection{Serum amyloid $A$}

Serum amyloid A (SAA) is a small hydrophobic protein $(9-14 \mathrm{kDa})$, which is found in serum associated with high density lipoprotein. In humans, four separate isoforms have been identified [46]. Of these, SAA1 and SAA2 respond to an acute phase reaction with increased production from the liver. In contrast, SAA4 is a constitutive protein that is produced normally at low concentrations and is not affected by the acute phase response. The SAA3 isoform is expressed in non-hepatic tissues during the acute phase response with increases found in lung, adipose tissue, ovarian granulosa, as well as in the mammary gland [47]. The mammary isoform (M-SAA3) has also been detected in bovine colostrum [32]. Among the functions ascribed to SAA have been reverse transport of cholesterol from tissue to hepatocytes, opsonisation, inhibition of phagocyte oxidative burst and platelet activation [15]. The M-SAA3 isoform found in colostrum stimulates the production of mucin from intestinal cells assisting the initiation of secretions from the neonatal intestine and helping to prevent bacterial colonization [48].

Enzyme linked immunosorbent assay (ELISA) is the commonest format for immunoassays of SAA. A cross species SAA immunoassay has been developed for measuring in veterinary medicine, that can be used in most species as the antibody shows species specificity for SAA [49]. In addition, the latex agglutination test and turbidimetric immunoassay has been validated for SAA determination [50].

\subsection{Fibrinogen}

Fibrinogen (Fbg), a precursor of fibrin, is also an acute phase protein, which has been used for many years to evaluate inflammatory and traumatic diseases in cattle, and is characterized by markedly increased synthesis in response to infection [51]. Fibrinogen is a $\beta$-globulin present in the plasma. It is composed of 3 polypeptide chains linked by disulfide bridges and a glycoprotein [52]. Fibrinogen is involved in homeostasis, providing a substrate for fibrin formation, and in tissue repair, providing a matrix for the migration of inflammatory-related cells [53]. Assays for fibrinogen have been largely dependent on its biological activity based on the rate of formation of insoluble fibrin in the presence of excess thrombin or on its precipitation following mild heat treatment [54].

\subsection{Albumin}

Serum albumin is the major negative acute phase protein. During the acute phase response the demand for amino acids for synthesis of the positive acute phase proteins is markedly increased, which necessitates reprioritization of the hepatic protein synthesis: albumin synthesis is down-regulated and amino acids are shunted into synthesis of positive acute phase proteins [55]. It has been reported that during the acute phase response 30 to $40 \%$ of the hepatic protein synthesizing capacity is used for production of positive acute phase proteins and the production of other proteins thus need to be diminished [56]. Albumin is responsible for about $75 \%$ of the osmotic pressure of plasma and is a major source of amino acids that can be utilized by the animal's body when necessary. In routine practice, albumin is usually measured by 
spectrophotometric methods, such as the bromcresol green assay. However, overestimation of albumin can occur in heparinized plasma samples assayed by this method [57].

\section{Acute phase proteins in pigs}

In the pigs, C-reactive protein, haptoglobin, $\alpha_{1}$-acid glycoprotein, and pig specific major acute phase protein were identified as the diagnostically most important acute phase proteins.

\subsection{C-reactive protein}

In the pigs, as in the dogs and humans, C-reactive protein (CRP) is the prototypical acute phase protein with major diagnostic value. This protein was the first acute phase protein to be described. Originally named for its ability to bind the C-polysaccharide of Streptococcus pneumoniae, CRP has been defined as an exquisitely sensitive systemic marker of inflammation and tissue damage [58]. C-reactive protein plays important roles in the protection against infection, clearence of damaged tissues, and regulation of the inflammatory response [59]. Structurally, CRP is a cyclic pentamer which binds with a variety of pathogenic bacteria or intracellular antigens of damaged cells, thus recognising foreign molecules and altered self [1].

Measurement of serum CRP is generally by immunoassays using specific CRP antibodies, and several formats have been developed and described for this purpose, such as immunoturbidimetric assay, ELISA, or latex agglutination tests [60,61]. Currently, a commercial ELISA kit is available that is specific for porcine CRP, although technical improvements are needed to decrease between-run imprecision.

\subsection{Alpha ${ }_{1}$-acid glycoprotein}

The main biochemical characteristic of $\alpha_{1}$-acid glycoprotein (AGP) is that it is a highly glycosylated protein and is the main protein component in seromucoid [62]. It does bind to a number of metabolites such as heparin, histamine and serotonin, steroids and catecholamines [63]. AGP is also known to bind to pharmacological compounds which may have therapeutic implications as the amount bound can affect the metabolically active fraction of the drug. Increased AGP due to an acute phase response thus may reduce the concentration of free drugs, thus affecting their pharmacokinetics.

Although AGP can be estimated by precipitation of the majority of serum proteins by perchloric acid and quantification of the remaining soluble proteins, this protein is usually measured by single radial immunodiffusion on agarose gel impregnated with anti-species AGP rabbit serum [64]. These tests are species-specific; however, they have the disadvantage of requiring 24 or 48 hours for diffusion to be complete.

\subsection{Pig specific major acute phase protein}

Specifically in the pigs, this specific acute phase protein (pig MAP) of unknown function has been reported to be a sensitive indicator of infection. Increases in pig MAP have been shown 
during infections with Actinobacillus pleuropneumoniae, in post weaning multisystemic wasting disorder and following transport [65]. The application of this protein to the veterinary diagnosis seems promising but needs further investigation.

\section{Acute phase proteins in cattle diseases}

\subsection{Acute phase proteins in calves}

\subsubsection{Acute phase proteins in calves with respiratory diseases}

Respiratory diseases are one of the leading causes of morbidity and mortality in calves and young cattle, and may account for serious economic losses [66]. In case of dairy calf pneumonia, diagnosis and treatment are mainly based on the observation of clinical symptoms, such as depression and body temperature combined with specific disease signs. However, in many cases, the infected calves show only mild clinical symptoms that could be easily missed in a group of calves on a farm [67]. To prevent disease outbreaks, early detection, isolation and treatment of diseased animals is important. Therefore, there is a need for objective parameters that are suitable as indicators of health or disease in calf herds applicable in the laboratory diagnosis of diseases. These proteins have been found to increase in the serum of cattle with many different diseases, including experimentally induced and naturally occurring respiratory tract diseases [40].

Respiratory-tract diseases are considered to be multi-factorial with causative agents, calf factors and environmental factors. The most common agents found in association with respiratory diseases are viruses such as bovine respiratory syncytial virus (BRSV), bovine herpesvirus (BHV-1), parainfluenza- virus (PI-3). On the other hand, secondary bacterial infections, e.g. Mannheimia haemolytica, Pasteurella multocida, Histophilus somni are common [68]. However, scientist are not in agreement as to whether bacterial or viral infections mount a higher response. Conner et al. [69] showed that intra-tracheal aerosol inoculation with Mannheimia (M.) haemolytica in calves raised the levels of haptoglobin, $\alpha_{1}$-antitrypsin, and seromucoid. The aforementioned authors showed the earliest detectable rise in the concentrations of Hp after 24 hours, with the highest value on day 3 after inoculation $(1.0 \mathrm{~g} / \mathrm{l})$. Similar to previous data reported by Makimura and Suzuki [43], the Hp concentrations were undetectable (less than $30 \mu \mathrm{g} / \mathrm{ml}$ ) in animals prior to challenge. These data provide valuable information regarding the induction and kinetics of haptoglobin production. Horadagoda and Eckersall [70] evaluated also calves intra-tracheally infected with M. haemolytica serotype A1. The results reported by these authors showed a small, insignificant increase in Hp concentrations within $10 \mathrm{~h}$ post-inoculation. In contrast, the concentrations of serum amyloid A increased progressively from undetectable values at inoculation to $18 \mathrm{mg} / \mathrm{l}$ measured 10 hours after the infection. These data indicate that SAA is a more rapidly reacting acute phase protein compared to haptoglobin in response to bacterial infection with M. haemolytica. On the other hand, Angen et al. [71] reported that even if SAA is more rapidly reacting acute phase protein, 
it needs virus to be present in order to respond, while $\mathrm{Hp}$ is fully induced by bacterial infection alone.

Godson et al. [40] investigated the serum protein profile from animals with bovine respiratory diseases to identify bovine acute phase proteins which may be used as indicators of the disease. For this reason, they experimentally reproduced bovine respiratory diseases, by challenging seronegative calves with bovine herpesvirus (BHV-1) on day 0 and M. haemolytica A-1 strain on day 4, which mimics the clinical signs and pathological changes associated with the naturally occuring fibrinous pneumonia observed in feedlots. In this model of virus induced bacterial pneumonia, the aforementioned authors found only few animals responding to the viral challenge with increased haptoglobin concentrations. Over the first 4 days after BHV-1 exposure, only $10 \%$ of animals developed Hp concentrations higher than $100 \mu \mathrm{g} / \mathrm{ml}$. However, 24 hours after $M$. haemolytica challenge, $43 \%$ of the animals had Hp values in excess of $100 \mu \mathrm{g} /$ $\mathrm{ml}$, and 3 days after challenge, this proportion reached $84 \%$. Moreover, the proportion of animals responding and the mean $\mathrm{Hp}$ concentration continued to rise for another $2-3$ days. Thus, according to Godson et al. [40], haptoglobin induction appeared to be related to the onset of bacterial infection. Moreover, in the aforementioned study, the induction of haptoglobin production was temporally associated with the development of the disease, as well as the disease severity (fever, sick score, weight loss). While all animals which were clinically sick had elevated Hp concentrations, increased Hp values were detected also in some animals that did not show apparent illness. Thus, the measurement of Hp may detect infected animals before clinical signs of the disease become apparent [25]. Furthermore, Godson et al. [40] reported significantly higher Hp concentration in animals that subsequently died compared to those that recovered. Similar findings were reported by Tóthová et al. [72] in calves suffering from bovine respiratory disease under field conditions. Therefore, the determination of Hp concentrations may serve as a prognostic aid in determining the severity of the disease. Further examination of the acute phase response of calves to bacterial infection with Pasteurella multocida biotype A3 was performed by Dowling et al. [73] to describe the changes in acute phase reactants of the host to either low or high volumes of the inocula. The results of the aforementioned authors showerd that all treatments elicited a moderate to severe response and induced clinical signs characteristic of bovine pneumonic pasteurellosis as observed in natural cases. However, the results of the acute phase reactants indicated that, of the two treatment variables used (dose and volume), volume was the more influential factor inducing the disease. In calves challenged with greater volumes ( $300 \mathrm{vs} .60 \mathrm{ml})$ they found significantly higher Hp concentrations, regardless of the number of the bacteria $\left(10^{9} \mathrm{vs} .10^{10} \mathrm{cfu}\right)$. Dowling et al. [73] expected that increased volume challenges affect a greater area of the lungs, especially if the initially slow response in Hp production provides more time for bacterial proliferation. Moreover, they stated that the increases in the concentrations of $\alpha_{1}$-acid glycoprotein were more gradual than those observed for Hp and maintained for longer period.

Heegaard et al. [25] evaluated the acute phase response of calves to experimental viral infection with bovine respiratory syncytial virus (BRSV). While the serum concentrations of both serum amyloid $\mathrm{A}$ and haptoglobin remained low in all control animals in this study, the SAA concentrations became elevated in the most of experimentally infected animals. This elevation 
was detectable at day 5 after infection, and peaked around day $5-8$ post infection. The highest SAA concentrations were in the range of $60-80 \mu \mathrm{g} / \mathrm{ml}$, which is about $5-7$ times higher than the values obtained in the control animals. Generally, changes in Hp concentrations followed the changes in SAA values. The maximum response of $\mathrm{Hp}$ was seen on day $6-7$ after infection, and reached $8-10 \mathrm{mg} / \mathrm{ml}$. In the study by Heegaard et al. [25], SAA responded more rapidly to infection, but $\mathrm{Hp}$ concentrations correlated better with disease severity. Similar findings were reported by Grell et al. [74] in calves experimentally infected with BRSV with the highest Hp concentrations at 7-9 days after inoculation. Moreover, calves with the most severe clinical symptoms had the highest Hp values. Gänheim et al. [67] examined the acute phase response in calves experimentally infected in the respiratory tract with either bovine viral diarrhoea virus (BVDV) or M. haemolytica, or with a combination of the two agents. They investigated also the differences in the magnitude and kinetics between single and dual infection. In all inoculated groups, a significant acute phase response was observed with elevated values of $\mathrm{Hp}$, SAA, as well as fibrinogen, while the control group remained unaffected throughout the study. In general, the magnitude of the response was similar, but the duration of increased concentrations of measured acute phase proteins were the longest in the BVDV/M. haemolytica group, reflecting the duration of the clinical symptoms. According to the data obtained by Gänheim et al. [67], the acute phase response occured much faster after M. haemolytica inoculation than after BVDV infection. After BVDV inoculation, increases in the acute phase protein concentrations did not appear until $7-8$ days.

\begin{tabular}{llll}
\hline Variables & \multicolumn{2}{l}{ Group of calves } & P \\
\cline { 2 - 4 } & Healthy $(\mathbf{n}=\mathbf{1 5})$ & Sick $(\mathbf{n}=\mathbf{2 7})$ & $<0.001$ \\
\hline $\mathrm{Hp}(\mathrm{mg} / \mathrm{ml})$ & $0.05 \pm 0.06$ & $1.11 \pm 0.80$ & $<0.01$ \\
\hline SAA $(\mu \mathrm{g} / \mathrm{ml})$ & $28.02 \pm 20.60$ & $63.19 \pm 39.42$ & \\
\hline
\end{tabular}

$\mathrm{P}$ - significance of the differences in measured values between healthy and sick animals, n. s. - non significant

Table 2. Concentrations of $\mathrm{Hp}$, and SAA in healthy animals and calves suffering from chronic respiratory diseases $($ mean \pm SD) [72]

According to Nikunen et al. [75], the use of different acute phase proteins as markers of naturally occuring respiratory diseases is somewhat controversial. In the study presented by these authors, only Pasteurella multocida infection was associated with markedly increased concentrations of acute phase proteins. Similarly, Svensson et al. [76] concluded that the discriminative ability of serum $\mathrm{Hp}$ concentrations for indicating the clinical respiratory-tract disease in calves under field conditions is overall poor, and no better than rectal temperature. The usefulness of acute phase proteins for determining the response to therapy and making the right treatment decisions was evaluated by Carter et al. [77]. They found higher Hp concentrations in calves requiring more than one treatment compared to calves with one treatment. In addition, Berry et al. [78] showed that Hp concentrations are useful tool for predicting the number of antimicrobial treatments required in newly received feedlot calves. 
The ability of acute phase proteins to clearly identify the calves with bronchopneumonia that would have required an anti-inflammatory treatment was investigated also by Humblet et al. [79]. The results presented by these authors showed that haptoglobin and fibrinogen together in growing calves suffering from bronchopneumonia allow the identification of about $70 \%$ of calves that required antibiotic and anti-inflammatory drugs. Haptoglobin alone was able to confirm $>75 \%$ of case decisions, whether diseased calves were treated or not. Moreover, Hp and Fbg were useful predictors of the inflammation severity. Jawor and Stefaniak [80] evaluated selected acute phase proteins and their usefulness as parameters for monitoring the treatment of respiratory diseases in calves. According to the aforementioned authors, the decreasing concentrations of acute phase proteins observed in the majority of calves treated for bronchopneumonia suggest diminishing inflammatory processes. In contrast, higher acute phase protein concentrations after an initial decrease strongly suggest the presence of secondary infections, meening that treatment should be continued.

\begin{tabular}{llll}
\hline Variables & Group of sick calves & P \\
\hline & A $(\mathbf{n}=\mathbf{1 6})$ & B $(\mathbf{n}=\mathbf{1 1})$ & \\
\hline Hp $(\mathrm{mg} / \mathrm{ml})$ & $0.81 \pm 0.60$ & $1.56 \pm 0.86$ & $<0.05$ \\
\hline SAA $(\mu \mathrm{g} / \mathrm{ml})$ & $44.70 \pm 30.78$ & $90.07 \pm 35.73$ & $<0.01$ \\
\hline
\end{tabular}

Groups of calves: A - group of calves with improved general health state; B - group of died or euthanised calves

$\mathrm{P}$ - significance of the differences in measured values between two groups of sick calves, n. S. - non significant

Table 3. Comparison of the concentrations of $\mathrm{Hp}$, and SAA between two groups of calves with respiratory-tract diseases, divided according to the development of their health status during the treatment (mean \pm SD) [72]

Most of the investigations on the synthesis of acute phase proteins in animals with respiratory diseases have been focused on the immediate or acute phase response of the infection. However, only a few reports on the acute phase protein production in chronic inflammatory conditions have been published. Horadagoda et al. [18] found that the concentrations of Hp, SAA and $\alpha_{1}$-acid glycoprotein were higher in cases of acute compared with chronic inflammation. The results presented by Tóthová et al. [72] showed that not only acute diseases of the respiratory tract, but also chronic cases are characterized with increased production of some acute phase proteins, predominantly haptoglobin with concentrations in calves with chronic respiratory diseases more than twentyfold higher compared with healthy animals (Table 2). In addition, in the aforementioned study, cases with severe clinical signs and poor prognosis were associated with markedly higher $\mathrm{Hp}$ and SAA concentrations (Table 3). Thus, Hp concentrations in the range of $1-3 \mathrm{mg} / \mathrm{ml}$, and SAA concentrations around $100 \mu \mathrm{g} / \mathrm{ml}$ predict severe course of the disease with poor prognosis. Similar findings were reported in calves by Heegaard et al. [25]. Skinner et al. [81] found that Hp concentrations of more than $0.2 \mathrm{mg} / \mathrm{ml}$ indicate mild infection, values above $0.4 \mathrm{mg} / \mathrm{ml}$ suggest severe infection, while extended pathological conditions are typically associated with $\mathrm{Hp}$ values in the range of $1-2 \mathrm{mg} / \mathrm{ml}$. These results suggest the wide use and possible application of acute phase proteins to 
determine respiratory diseases and the magnitude of inflammatory changes in calves, choose proper therapy and monitor the efficiency of the treatment.

\subsubsection{Acute phase proteins in calves with diarrhoea}

Diarrhoea in calves, together with respiratory diseases, is another multifactorial disease entity that can have serious financial and animal welfare implications in both dairy and beef suckler herds. It has been estimated that $75 \%$ of early calf mortality in dairy herds is caused by diarrhoea in the pre-weaning period [82]. However, there are only few published data regarding the possible influence of diarrhoea on the concentrations of acute phase proteins and their usefulness in the diagnosis of these diseases. Piercy [83] investigated the production of ceruloplasmin in experimental infection with Salmonella (S.) Dublin. In the infected calves, they found a significant increase in the concentrations of ceruloplasmin between 3 and 4 days after infection, which decreased to normal values on day 7. Deignan et al. [84] examined the serum concentrations of haptoglobin, a more common bovine acute phase protein, in young calves in response to experimental infection with a mixture of three Salmonella serotypes (S. Dublin, S. enteritidis, S. Heidelberg), and to compare these levels with clinical markers of infection to assess the usefulness of $\mathrm{Hp}$ as a marker of infection severity. In the aforementioned study, the serum Hp concentrations prior to bacterial challenge were undetectable in all animals included in the trial. Following experimental Salmonella infection, the Hp concentrations increased significantly within 3 days of challenge. This increase in serum Hp values showed a statistical correlation with other more subjective clinical markers of infection, such as diarrhoeal scores, morbidity scores and temperature. On day 5 post-challenge, the serum Hp concentrations in Salmonella-challenged calves had returned to the normal values in all animals analyzed, despite the persistence of clinical symptoms of infection in the most of these animals. These obtained data indicate that Hp concentrations reflect the severity of infection, and may aid in predicting the prognosis of the infection. Similarly, Skinner et al. [81] indicated the significance of $\mathrm{Hp}$ as a clinically useful parameter for measuring the occurrence of enteritis in cattle.

The usefulness of the assessment of Hp, SAA and fibrinogen concentrations for the monitoring of treatment in calves having diarrhoea was evaluated by Jawor [85]. In the aforementioned study, $40 \%$ of calves with diarrhoea had Hp concentration $>0.1 \mathrm{mg} / \mathrm{ml}$ (ranging to $0.49 \mathrm{mg}$ / $\mathrm{ml}$ ). During the treatment, the serum concentrations of $\mathrm{Hp}$ decreased. A high percentage of diarrhoeic calves with higher Fbg concentrations (mean Fbg concentration of $7.28 \mathrm{~g} / \mathrm{l}$ ) were detected at the beginning of the treatment, while during the treatment a gradual decrease was noted. However, fibrinogen estimation required an additional determination of plasma proteins to distinguish between a relative increase in hemoconcentration and an absolute increase of Fbg concentration during inflammation [53]. The concentrations of SAA were elevated during the entire treatment period for most of the diarrhoeic calves. The very high initial serum SAA concentrations and subsequent significant decrease of values during the treatment suggest that this acute phase protein may be very useful in calves with diarrhoea. Similarly, the results presented by Tóthová et al. [86] showed in 10 calves with clinical signs of diarrhoea higher mean SAA concentration compared with clinically healthy calves (Table 
4). However, in Hp and Fbg concentrations they found no marked differences between healthy and diarrhoeic calves, and haptoglobin does not reach the concentrations seen in other disease conditions in cattle. Thus, these findings indicate that the disturbances in the homeostasis, inflammatory reactions of the organism, and tissue damage caused by diarrhoea did not evoke sufficient inflammatory response giving a more marked systemic increase in the concentrations of measured acute phase proteins. Similarly, according to Muller-Doblies et al. [87], Hp requires a stronger stimulation to induce an increase in serum concentrations.

\begin{tabular}{|c|c|c|c|c|c|c|c|}
\hline \multirow[t]{2}{*}{ Variables } & & \multicolumn{5}{|c|}{ Groups of calves } & \multirow{2}{*}{$\begin{array}{l}\mathrm{K}-\mathrm{W} \\
-P\end{array}$} \\
\hline & & $\mathbf{H}$ & A & B & C & D & \\
\hline \multirow[t]{2}{*}{$\mathrm{Hp}(\mathrm{mg} / \mathrm{ml})$} & $x$ & $0.04^{a}$ & $0.73^{a}$ & 0.10 & 0.13 & 0.43 & \multirow[t]{2}{*}{$<0.001$} \\
\hline & SD & 0.03 & 0.78 & 0.16 & 0.16 & 0.78 & \\
\hline \multirow[t]{2}{*}{ SAA $(\mu \mathrm{g} / \mathrm{ml})$} & $x$ & $29.78^{a}$ & $93.38^{a}$ & 51.47 & 74.94 & 42.02 & \multirow[t]{2}{*}{$<0.001$} \\
\hline & SD & 24.62 & 50.96 & 25.05 & 26.16 & 28.21 & \\
\hline \multirow[t]{2}{*}{$\mathrm{Fbg}(\mathrm{g} / \mathrm{l})$} & $x$ & $2.31^{\mathrm{a}}$ & $3.86^{\mathrm{a}}$ & 2.84 & 2.81 & 3.16 & \multirow[t]{2}{*}{$<0.001$} \\
\hline & SD & 0.41 & 1.55 & 0.77 & 0.51 & 1.22 & \\
\hline
\end{tabular}

The same superscripts in rows mean statistical significance of differences in measured concentrations between the groups of calves: $\mathrm{a}-\mathrm{P}<0.001$

K-W - Kruskal-Wallis analysis; P - significance of the analysis

Groups of calves: $\mathrm{H}$ - clinically healthy calves, A - calves with clinical signs of respiratory diseases, B-diarrhoeic calves, C - calves with omphalophlebitis, D - calves with multisystemic diseases

Table 4. Comparison of the concentrations of $\mathrm{Hp}$, SAA and Fbg between clinically healthy calves and calves affected by various inflammatory diseases [86]

\subsubsection{Acute phase proteins in calves with omphalophlebitis and multisystemic diseases}

Seeing that the inflammation of the navel, the tissue damage and other pathologic lesions in the associated structures may cause inflammatory reactions, Tóthová et al. [86] evaluated calves with omphalophlebitis to detect if this disease may affect the concentrations of major acute phase proteins. The results presented in this study showed in calves with clinical signs of omphalophlebitis, similarly to the calves with diarrhoea, more markedly higher mean concentration of SAA than in clinically healthy calves. In the concentrations of $\mathrm{Hp}$ and Fbg there were no marked differences between healthy and sick animals (Table 4). These findings might be a consequence of a different initiation of the production of various acute phase proteins, seeing that SAA is a more sensitive acute phase protein than Hp in cattle, with rapid increase in serum concentrations after the inflammatory stimulus [88]. An opposite trend with more markedly higher mean concentrations of $\mathrm{Hp}$ and Fbg was observed by Tóthová et al. [86] in calves affected by multisystemic diseases (with more than one affected organ - navel, joints, digestive tract, respiratory system), while the mean SAA concentration obtained in this group was only slightly higher compared with clinically healthy calves. Similar findings were 
reported by Gänheim et al. [89], who found higher concentrations of Hp and fibrinogen in calves with diarrhoea at the same time as respiratory symptoms compared to those that had signs of only respiratory diseases or diarrhoea.

\subsection{Acute phase proteins in dairy cows}

\subsubsection{Acute phase proteins in cows with mastitis}

Despite world-wide efforts, mastitis has remained economically the most important disease in dairy cattle, and despite different mastitis control programs it is still the major challenge for the dairy industry [90]. While clinical mastitis is often easy to detect, sub-clinical mastitis, on the otherhand, is alarger problem for the dairy ind ustry sincethis condition shows novisiblechanges in the udder or in the milk [91]. Sub-clinical mastitis is frequently diagnosed by Californian Mastitis Test (CMT), which may suffer from a lack of reproducibility. In addition, up to now, the evaluation of somatic cell count (SCC) has remained as the gold standard for determining udder health. However, it is not sufficient enough in discriminating between the clinical and subclinical form of mastitis [92]. Therefore, it is of great importance to investigate biomarkers that could be used for rapid detection of sub-clinical mastitis. One of the ways to identify cows with sub-clinical mastitis would be the measuring of the concentrations of acute phase proteins. The production and usefulness of acute phase proteins in cows with experimentally induced mastitis and mastitis under field conditions were investigated by several authors.

Conner et al. [93] evaluated the concentrations of haptoglobin, ceruloplasmin and $\alpha-1$ antitrypsin in cows with summer mastitis (septic mastitis) and clinically healthy cows. In all cows with mastitis, they found elevated concentrations of $\mathrm{Hp}$, whereas in healthy cows the Hp values were undetectable. Moreover, all cows with summer mastitis included into this study had significantly higher concentrations of ceruloplasmin and $\alpha-1$ antitrypsin in comparison to cows without mastitis. Skinner et al. [81] concluded that Hp concentrations of $0.2 \mathrm{~g} / \mathrm{l}$ and above in cows with mastitis may indicate early or mild infection, while values higher than $0.4 \mathrm{~g} / \mathrm{l}$ indicate severe infection.

The usefulness of acute phase proteins in the diagnosis of mastitis was investigated by Hirvonen et al. [94] in pregnant heifers experimentally infected with Actinomyces pyogenes, Fusobacterium necrophorum and Peptostreptococcus indolicus. They evaluated also the prognostic value of selected acute phase proteins (haptoglobin, fibrinogen, acid-soluble glycoproteins and $\alpha_{1}$ proteinase inhibitor) in the infected animals. According to the aforementioned authors, fibrinogen was a reliable indicator for detecting the presence of bacterial infection in all heifers, but not as a prognostic indicator for mastitis, as they found no significant differences in the production of Fbg between animals which recovered and those without response to treatment. They indicated Hp and acid-soluble glycoproteins as the most effective markers in the determination of the severity of infection and in predicting the final outcome of the disease in heifers with mastitis. The concentrations of $\mathrm{Hp}$ increased significantly in the infected heifers with the maximum values reached after $2-3$ days after inoculation. However, the Hp response was different between moderate and severely affected animals. Hirvonen et al. [94] reported that in severely infected heifers, the concentrations of $\mathrm{Hp}$ were four times higher than 
in the moderately affected heifers, and these values remained elevated 2 weeks after bacterial inoculation. On the other hand, in the moderately affected heifers, haptoglobin returned to normal values 5 days after the bacterial challenge. In a later study, Hirvonen et al. [95] examined the changes in some acute phase proteins in cows with acute experimental Escherichia (E.) coli mastitis and their role in predicting the outcome from the disease. The cows included into this study were challenged with $1500 \mathrm{cfu}$ of E. coli FT238 strain into one udder quarter, and 3 weeks later into the contralateral quarter. In the aforementioned study, the intramammary infection with E.coli produced a clinical mastitis and induced an increase in the serum Hp and SAA concentrations in all cows. The concentrations of Hp were normalized within 7 days, and SAA values by the 6th day after inoculation. In addition, these authors found that the differences between severely versus moderately or mildly affected cows with $E$. coli were present for SAA, but not for Hp. The concentrations of SAA were related to the severity of the disease; in cows with fatal mastitis the SAA concentrations progressively rose. Thus, serum amyloid A appeared to be a promising indicator for the course of $E$. coli mastitis. Similar findings were reported by Eckersall et al. [96] in cows with clinical mastitis (bacteria isolated including E. coli, Staphylococcus aureus, Streptococcus uberis, Streptococcus dysgalactiae and Arcanobacter pyogenes). They found significantly higher serum concentrations of Hp, as well as SAA in cows with both mild and moderate mastitis compared to healthy cows. However, these authors observed no significant differences between the cows suffering from mild and moderate mastitis.

The hypothesis that the major acute phase proteins in cows may be transferred into milk during the acute phase response caused by mastitis was investigated by adapting the assays to measure the concentrations of proteins in milk. Eckersall et al. [96] reported also that the most of serum proteins leak into milk across the blood-mammary barrier as a result of the disruption caused by the inflammation due to mastitis. Moreover, milk seems to be a better sample material than serum for testing the concentrations of acute phase proteins during mastitis (easier and quicker sample collection without stressing the animals). The potential value of measuring the concentrations of acute phase proteins in milk as a means of detecting mastitis in cows was assessed by Eckersall et al. [96]. According to their results, the milk samples from cows with both mild and moderate mastitis had significantly higher $\mathrm{Hp}$, as well as SAA concentrations than the milk from healthy cows. Moreover, in milk samples from cows with moderate mastitis, the SAA concentrations were significantly higher than in cows with mild mastitis. On the other hand, in the milk Hp concentrations there were no significant differences between the infected cows. Thus, the milk SAA concentrations seem to have a greater potential for the detection of the severity of mastitis, since it has higher sensitivity and specificity in differentiating cows with mastitis [96].

The SAA response in milk and plasma to experimental intramammary inoculation of $E$. coli in cows was examined by Jacobsen et al. [97]. In this study, plasma and milk samples were obtained from cows before and after intramammary inoculation with $50 \mathrm{cfu}$ of a non-verotoxic encapsulated strain of $E$. coli O:157. Prior to inoculation, the plasma and milk samples had no or very low concentrations of serum amyloid A. All cows, regardless of the severity of infection, showed elevated SAA concentrations in milk and plasma after inoculation. Milk SAA concentrations began to increase between 6 and 12 hours after inoculation (approximately 80 
times), and plasma SAA values increased between 12 and 24 hours post inoculation. The rapid increase in milk concentrations after intramammary inoculation of mastitis pathogens suggests that SAA may be particularly suited for early detection of mastitis [98]. The fast return towards baseline values after bacterial clearance suggests that milk SAA measurements may also be used as indicators of treatment efficiency. In the study presented by Jacobsen et al. [97], cows with severe mastitis had a particularly increased milk SAA concentrations at 48 hours after inoculation, which stayed elevated throughout the study period. In cows with moderate and mild mastitis, milk SAA values started to decrease at 60 and 48 hours after inoculation, respectively. As cows with severe mastitis had higher milk SAA concentrations than cows with moderate or mild mastitis, SAA may therefore serve as an indicator of the degree of tissue damage and hence prognosis and expected production loss during episodes of mastitis. Higher concentrations of $\mathrm{Hp}$ and SAA in serum and milk of cows with clinical mastitis were observed also by Nielsen et al. [99]. In addition, these authors concluded that the concentrations of acute phase proteins in milk significantly increased with increasing somatic cell count, which suggest that these protein may indicate the severity of the infection.

Grönlund et al. [100] examined the concentrations of Hp and SAA in cows with naturally occuring chronic sub-clinical mastitis. The comparison of acute phase protein concentrations in quarter and composite milk samples was made also in this study. Almost all quarter milk samples from healthy control cows had undetectable concentrations of Hp and SAA. In cows with chronic sub-clinical mastitis, increased concentrations of both measured acute phase proteins in milk were observed, indicating an activation of the acute phase response also in cows with chronic mastitis, but the contents of $\mathrm{Hp}$ and SAA varied markedly. Haptoglobin and SAA were detected by the aforementioned authors in $83 \%$ of the examined composite milk samples. Thus, according to Grönlund et al. [100], since cows had to have detectable concentrations of $\mathrm{Hp}$ or SAA in at least two udder quarters for elevated values to be found in the composite samples, analysis at the quarter level is preferable.

Further investigations showed an extrahepatic synthesis of specific isoform of serum amyloid A directly from mammary epithelial cells (M-SAA) [32]. Therefore, M-SAA is believed to be more sensitive indicator of mastitis, which accumulates in milk only during mammary inflammation. The usefulness of M-SAA in the diagnosis of clinical and sub-clinical mastitis in cows with various clinical findings on the mammary gland was investigated by Kováč et al. [101]. Their results showed markedly higher M-SAA concentrations in milk samples from quarters with clinical changes, as well as from quarters without clinical signs of mastitis, but with strongly positive Californian Mastitis Test (Table 5). In addition, the concentrations of MSAA found in samples from mammary quarters without clinical changes were also relatively high (mean value of $473.7 \mathrm{ng} / \mathrm{ml}$ ), as the uninfected mammary quarters had to have very low or undetectable concentrations of M-SAA. These results suggest that some quarters might be affected by inflammatory process, but still without positive reaction of CMT. Elevated concentrations of M-SAA in quarters with mastitis compared to healthy quarters were reported also by Petersen et al. [102] and Nazifi et al. [103]. 


\begin{tabular}{|c|c|c|c|c|c|c|}
\hline \multirow[t]{2}{*}{ Variable } & & \multicolumn{4}{|c|}{ Groups of cows } & \multirow{2}{*}{$\begin{array}{l}K-W \\
-P\end{array}$} \\
\hline & & I. $(n=7)$ & II. $(n=12)$ & III. $(n=13)$ & IV. $(n=9)$ & \\
\hline \multirow{2}{*}{$\begin{array}{l}\text { M-SAA } \\
(\mathrm{ng} / \mathrm{ml})\end{array}$} & $x$ & $325.7^{A, B}$ & $1433.1^{\mathrm{a}}$ & $3910.4^{A}$ & $6073.8^{\mathrm{B}, \mathrm{a}}$ & \multirow[t]{2}{*}{$<0.001$} \\
\hline & $\pm S D$ & 173.8 & 949.2 & 2145.8 & 4414.0 & \\
\hline \multirow[t]{2}{*}{$\mathrm{Hp}(\mathrm{mg} / \mathrm{ml})$} & $x$ & 0.046 & 0.122 & 0.299 & 0.329 & \multirow[t]{2}{*}{$<0.05$} \\
\hline & $\pm S D$ & 0.053 & 0.263 & 0.314 & 0.339 & \\
\hline \multirow[t]{2}{*}{ SAA $(\mu \mathrm{g} / \mathrm{ml})$} & $x$ & 29.7 & $27.6^{a}$ & 48.2 & $71.5^{\mathrm{a}}$ & \multirow[t]{2}{*}{$<0.05$} \\
\hline & $\pm S D$ & 27.6 & 28.0 & 42.5 & 31.5 & \\
\hline
\end{tabular}

The same superscripts in rows mean statistical significance of differences in measured concentrations between the groups of cows: $\mathrm{a}-\mathrm{P}<0.05 ; \mathrm{A}, \mathrm{B}-\mathrm{P}<0.001$

$\mathrm{K}-\mathrm{W}$ - Kruskal-Wallis analysis; $\mathrm{P}$ - significance of the analysis

Groups of cows: I - cows without clinical findings on the mammary gland and with negative CMT, II - cows without clinical findings on the mammary gland and with weakly positive CMT, III - cows without clinical findings on the mammary gland and with strongly positive CMT, IV - cows with clinical changes and changes in the milk appearance

Table 5. The concentrations of M-SAA, Hp, and SAA in dairy cows with various findings on the mammary gland [101]

The response characterized by increased synthesis of M-SAA is specific for the quarter and does not necessarily result in detectable concentrations in composite milk samples. The results presented by Kováč et al. [101] showed similar trend of changes in the concentrations of MSAA in composite milk samples and in samples from separate quarters, but the values measured were lower in composite milk samples, which suggest a diluting effect of milk from quarters with less marked changes (Table 5). Grönlund et al. [100] reported also some interpretative problems by the use of composite milk samples if only one quarter is sub-clinically infected. Therefore, it seems that composite milk samples are less suitable for detection of subclinical mastitis than samples from separate mammary quarters. In addition, the results presented by Kováč et al. [101] showed in cows with clinical mastitis higher concentrations of Hp and SAA in blood serum (Table 5), which suggest that localized severe inflammation of the udder is sufficiently intense to induce a measurable systemic acute phase response. However, the finding that the differences in serum Hp and SAA concentrations observed between the groups of cows with various clinical findings on the mammary gland were less significant than the differences in M-SAA concentrations means that the measuring of serum concentrations of some acute phase proteins would be less useful to the evaluation of the severity of mastitis than the measuring of the concentrations of M-SAA directly in milk samples.

\subsubsection{Acute phase proteins in cows after parturition and cows with peripartum reproductive disorders}

The period after parturition is the most critical period in dairy cows regarding health status and production. Factors such as pregnancy, parturition, blood calcium concentrations, initiation of lactation and feed intake all affect the ability of the cow's immune system to effectively combat infections. The periparturient period is the time where these complex 
physiological changes occur simultaneously, having a significant effect on the animal's health [104]. Parturition, changes in homeostasis, metabolic and physiological challenges occuring in this stressful period, as well as other external and internal harmful stimuli may contribute to the activation of host immune system and inflammatory responses, including the initiation of the production of acute phase proteins. Major bovine acute phase proteins, haptoglobin and serum amyloid A, play an important role also in the reproductive processes, they intensify the phagocytosis process against the pathogens introduced into the uterus, and help by the reconstruction of the endometrium [105].

Saini et al. [106] reported that lactation and pregnancy in cattle appeared to have no effect on the Hp concentration in blood serum. However, according to Gymnich et al. [107] haptoglobin concentrations undergo significant changes around parturition, and in horses and cows the highest concentrations were observed 1 day post partum. Uchida et al. [108] evaluated the concentration of $\mathrm{Hp}$ in cows in the periparturient period and they observed significantly higher values around parturition than before and after parturition. Similarly, Ametaj [109] and Tóthová et al. [110] reported in cows after parturition an increase of two main acute phase proteins, Hp and SAA. According to the results presented by Chan et al. [111], the SAA concentrations in healthy cows reached the highest values within 3 days after the delivery (mean value of $66 \mathrm{mg} / \mathrm{l}$ ). The Hp concentrations in the most of the evaluated animals were higher than $130.9 \mathrm{mg} / \mathrm{l}$ within 3 days after calving. Parturition with following metabolic challenges constitutes a potentially stressful event for the dairy cow. One of the ways how an animal can manifest stress is in the form of activated acute phase response, including the increased production of acute phase proteins by the liver. According to Alsemgeest et al. [112], the physiological processes taking place around the time of parturition are mainly responsible for higher concentrations of acute phase proteins in blood serum. Regassa and Noakes [113] reported that higher values of acute phase proteins could be related to the tissue damage occuring due to the increased myometrial activity during expulsion of the calf, involution of the uterus, as well as degeneration and regeneration of the endometrium. Young et al. [114] found that higher concentrations of these proteins, determined in the last phase of pregnancy and after calving may be connected with the changing hormone profile (the influence of estrogens and progesterone). In addition, it is worth pointing out that the increase in acute phase protein concentrations in cattle may be caused also by the increased concentrations of cortisol [115].

Postpartum endometritis is a common problem in cattle, because uterine contamination following calving is frequent, but most cows are able to eliminate bacteria from the uterus within 2 to 3 weeks after calving without manifesting marked clinical signs of the disease. However, cows that can not eliminate the infection may subsequently develop endometritis. Skinner et al. [81] reported that Hp concentrations are high in cows with metritis, with mean serum Hp concentration in cows with severe metritis of $1.04 \mathrm{~g} / \mathrm{l}$. Chan et al.[116] evaluated clinically healthy cows and cows with postpartum reproductive diseases after calving, and the Hp concentrations in clinically diseased cows $(1133.5 \mathrm{mg} / \mathrm{l})$ were significantly higher than in clinically healthy cows (104.6 mg/l). In a later study presented by Chan et al. [111], cows with acute puerperal metritis had significantly higher Hp concentrations than those in healthy cows throughout the 
6 months after delivery. The highest $\mathrm{Hp}$ concentration was found in the period of 3 days after parturition $(1.1 \mathrm{~g} / \mathrm{l})$, and for SAA concentrations $4-7$ days post partum $(85 \mathrm{mg} / \mathrm{l})$. However, postpartum metritis does not necessarily need to be manifested by general clinical signs of the disease; frequently only subfertility and a decrease of the milkyield are found. Moreover, various cows with mild uterine inflammation are able to restore health spontaneously without more serious consequences. Low Hp concentrations were found by Smith etal. [117] in cows with toxic puerperal metritis. Hirvonen et al. [118] reported also that the Hp concentrations remained low or moderate in the most of cows with acute postpartum metritis. However, the data obtained in recent years suggest that acute phase proteins may be used as early predictors or risk factors for metritis. Huzzey et al. [119] showed that cows with Hp concentrations higher than $1 \mathrm{~g} / \mathrm{l}$ at day 3 post partum were 6.7 times more likely to develop mild or severe metritis. Similarly, Dubuc et al. [120] concluded that Hp concentrations higher than $0.8 \mathrm{~g} / \mathrm{l}$ in the first week after parturition are a risk factor for endometritis, as well as purulent vaginal discharge.

The usefulness of acute phase proteins by the evaluation of the efficiency of therapy was investigated by Mordak [121] in cows with retained placenta (with or without manual removal of the membrane). The highest Hp concentration they found in cows where the placenta had been expelled after 4 days $(2.22 \mathrm{~g} / \mathrm{l})$, and the lowest in cows where the placenta had been easily removed manually $(0.9 \mathrm{~g} / \mathrm{l})$.

\subsubsection{Acute phase proteins in cows with hoof diseases and lameness}

Bovine lameness and hoof diseases represent one of the major health problems for the dairy industry, and raise important questions about economic aspects and welfare issues in agriculture [122]. Economic losses arise from decreased milk production, poor performance, fertility problems, increasing culling rates and treatment costs. The predominant hoof problems causing lameness in cows are sole ulcers, white line abscesses, interdigital phlegmons and digital dermatitis [123]. Disorders in the locomotory system (due to damaged tissues, painfull processes, impaired homeostasis) may lead to a systemic acute phase response characterized by higher concentrations of some acute phase proteins. Therefore, some acute phase proteins may be useful in the early detection of lame cows in order to limit the losses related to lameness.

\begin{tabular}{llll}
\hline Variables & Groups of animals & & P \\
\hline Healthy $(\mathbf{n}=\mathbf{2 3})$ & Sick $(\mathbf{n}=\mathbf{3 5})$ & $<0.05$ \\
\hline $\mathbf{H p}(\mathrm{mg} / \mathrm{ml})$ & $0.094 \pm 0.086$ & $0.450 \pm 0.601$ & $<0.001$ \\
\hline $\mathbf{S A A}(\mu \mathrm{g} / \mathrm{ml})$ & $12.70 \pm 16.80$ & $113.90 \pm 55.66$ & $<0.001$ \\
\hline Fbg $(\mathrm{g} / \mathrm{l})$ & $2.19 \pm 0.37$ & $2.95 \pm 0.65$ & \\
\hline
\end{tabular}

$\mathrm{P}$ - significance of the differences in measured values between healthy and sick animals, n. s. - non significant

Table 6. Comparison of the concentrations of evaluated acute phase proteins in healthy animals and heifers with hoof diseases (mean \pm SD) [125] 
The usefulness of acute phase proteins in the detection of lame cows was evaluated by Kujala et al. [124]. They investigated the acute phase response, including the concentrations of Hp and SAA in cows with sole ulcers and white line diseases. Their results showed higher concentrations of SAA in lame cows than in healthy animals, with values elevated from day 0 until days $7-8$. The SAA concentrations started to decrease on day 14 . In the serum Hp concentrations, no significant differences between healthy and lame cows were found. Significantly higher concentrations of $\mathrm{Hp}$, SAA, as well as fibrinogen were found by Tóthová et al. [125] in heifers with hoof diseases (including pododermatitis, laminitis, sole ulcer, and digital dermatitis) compared to healthy animals (Table 6). Laven et al. [126] evaluated the concentrations of $\mathrm{Hp}, \mathrm{Fbg}$, ceruloplasmin and seromucoid in first lactation heifers with hoof horn haemoorhagies to determine the relationships with the development of the disease. However, they found any relationships between the presence of acute phase response and the development of hoof horn haemorrhagies in heifers after calving.

The presence of acute phase response in association with lameness due to claw disorders was investigated by Smith et al. [127] in dairy cattle on a commercial farm. In addition, they evaluated the effect of treatment on the acute phase protein concentrations and thus measured the effectiveness of the treatment. Into the evaluation they included cows diagnosed with pododermatitis septica, pododermatitis circumscripta, interdigital necrobacillosis and papillomatosis, digital dermatitis, as well healthy cows as control animals. The concentrations of serum $\mathrm{Hp}$ of all healthy cows without lameness were undetectable. Lame cows with any of the presented claw disorders were found to have increased serum Hp concentrations. In animals with pododermatitis septica and interdigital necrobacillosis, the Hp concentrations decreased after the treatment between days 1 to 5 , which indicated effective treatment for these disorders. In contrast, treatment did not affect the concentrations of $\mathrm{Hp}$ in animals with pododermatitis circumscripta. Jawor et al. [128] evaluated the concentrations of acute phase proteins at selected time points during the treatment of cows with limb diseases with an aid to monitor the treatment and as an early predivtive marker of possible complications. In the examined cows, arthritis, sole ulcer, and white line disease were the most often diagnosed diseases. The highest concentrations of Hp, SAA and Fbg were recorded at the beginning of the treatment. In the cows, in which the treatment process went without complications, a high gradual decrease of acute phase protein concentrations was observed. This proved that the treatment applied was appropriate and that it contributed towards reducing the inflammatory process in cows. In cows with further complications (e.g. wound infections, bronchitis, the occurence of other inflammatory states of the limbs), they found increases in one or two of the measured acute phase proteins at the next blood collection. This indicates that these cows had not completely recovered and the treatment should be continued.

\subsubsection{Acute phase proteins in cows with abdominal disorders}

The usefulness of the measurement of acute phase protein concentrations in cattle, predominantly of fibrinogen, has been described in traumatic pericarditis, reticuloperitonitis, abomasal displacement, and by the monitoring of postoperative complications, as well as by the differentiation of reticuloperitonitis from other gastrointestinal disorders [51,129]. Very high 
plasma Fbg concentrations were reported by McSherry et al. [130] in cows with pericarditis and peritonitis.

After abdominal surgery, the condition of the patient is usually followed-up by physical observation. As complications are frequent, a more accurate indicator of their occurrence and severity would be valuable. Therefore, Hirvonen and Pyörälä [51] evaluated the usefulness of Fbg and $\mathrm{Hp}$ in the diagnosis of traumatic reticuloperitonitis in dairy cows. In addition, they studied how abdominal surgery affects these parameters, and whether they can be used to predict recovery from abdominal disorders. In this study, the preoperative Fbg and Hp concentrations in cows with traumatic reticuloperitonitis were significantly higher than those for cows with abomasal displacement or explorative laparotomy. The plasma Fbg values in cows with traumatic reticuloperitonitis remained high for about 2 days after surgery. The Hp concentrations in these cows showed only a small increase, which was followed by a steady decrease during the late hospitalization phase. However, the concentrations of both Fbg and Hp remained above normal values at the time of hospital discharge. Moreover, the values measured correlated well with the clinical findings from those cows with traumatic reticuloperitonitis. Thus, Hirvonen and Pyörälä [51] concluded that these proteins may be attractive parameters for the evaluation in the diagnostic of traumatic reticuloperitonitis.

According to McSherry et al. [130], displacement of the abomasum does not usually induce a significant fibrinogen response. In the study presented by Jawor et al. [131] the Fbg concentrations in cows with displaced abomasum were within normal values. Significant changes during the post-operative monitoring were found only for SAA concentrations. Nazifi et al. [132] evaluated the possible relationships between cardiac diseases (functional murmurs, pathologic murmurs, endocarditis, and pericarditis) and the concentrations of acute phase proteins in dairy cattle. In this study, cases with pericarditis and endocarditis had higher Hp and SAA concentrations than the cows with functional and pathological murmurs. In addition, the concentrations of the both measured acute phase proteins were lower in cows with endocarditis than those measured in cows with pericarditis, which suggest that the measurement of acute phase proteins can be helpful in differentiating an acute inflammatory condition like pericarditis from other cardiac disorders.

\section{Acute phase proteins in swine diseases}

Acute phase protein testing offers a tool for assessing a health status also in pig production systems. An important practical aspect in the pig production is the sub-clinical condition that does not lead to overt disease but may cause suboptimal growth and decreased welfare. A number of investigations indicate the ability of acute phase protein measurements to reveal such conditions $[133,15]$. In addition, lower gaining pigs were found to have higher acute phase protein levels than high gaining pigs [134].

PorcineC-reactive protein has been found toriseinexperimental models of Mycoplasmahyorhinis, Toxoplasma gondii, Actinobacillus pleuropneumoniae and porcine reproductive and respiratory syndrome virus infection [135]. Sorensen et al. [136] evaluated the acute phase response in the 
pigs experimentally infected with Streptococcus (S.) suis serotype 2. Already on day 1 after inoculation, the CRP concentrations increased sharply in all animals and in general reached the maximum values between days 1 and 5 after infection, showing an approximately 10-fold increase as compared to initial values. From around day 8 post inoculation, the response started to decrease. The SAA concentrations rose sharply in all pigs on day 1 after infection with S.suis., and peaked already on days 1 and 2, reaching peak levels of at least30-40 times the values before infection. Regarding the Hp concentrations, its values increased from the day 1 after inoculation in all animals, but increase was less marked compared to CRP and SAA. In addition, the acute phase response following inoculation with $S$. suis was closely correlated with the clinical signs and pathological lesions typical to S. suis infection. Thus, Sorensen et al. [136] concluded the usefulness of acute phase proteins in the detection of ongoing S. suis infection. The usefulness of serum haptoglobin in the determination of progressive atrophic rhinitis in pigs was evaluated by Francisco et al. [137]. They investigated the serum Hp concentrations in growing swine after intranasal challenge with varying doses of Pasteurella (P.) multocida type D (toxigenicstrain) and Bordetella (B.)bronchiseptica. Whileincreasing doses of $P$. multocida tended to increase serum Hp concentrations, increasing the dose of B. bronchiseptica was associated with reduced $\mathrm{Hp}$ values in this model. Significant positive correlations of the Hp concentrations and atrophic rhinitis scores were found by the aforementioned authors, indicating that increased serum haptoglobin is associated with higher incidences of atrophic rhinitis in swine. Quereda et al. [138] investigated the diagnostic value of acute phase proteins in the determination of pig infectious wasting diseases. They evaluated pigs from farms in which postweaning multisystemic wasting syndrome (PMWS) and porcine respiratory disease complex (PRDC) were diagnosed. In this study, serum Hp concentrations were significantly higher in pigs with PMWS and PRDC than in the specific pathogen free pigs. The serum CRP and SAA concentrations were significantly higher in pigs with PMWS than in healthy pigs. However, there were no significant differences for these proteins between healthy and PRDC pigs. In addition, Quereda et al. [138] concluded thatCRP andSAA could beused as a complementary tool to monitor theexistence of lymphoid depletion, and Hp could provide information about the severity of this depletion.

The relationships between the serum concentrations of acute phase proteins and the appearance and severity of lesions in pigs at slaughter was evaluated by Pallarés et al. [139]. They determined whether the concentrations of acute phase proteins could be used as markers for the presence of lesions and as a tool to detect sub-clinical disease in fattening pigs. In the aforementioned study, the concentrations of CRP in pigs with clinical signs of diseases and poor body conditionweresignificantlyhigher thanin apparentlyhealthy pigs with grosslesionsat slaughter (about 2.1 fold higher) and in apparently healthy pigs without gross lesions at slaghter (about 2.6 higher). Moreover, they found significant differences between apparently healthy pigs with marked lesions and without marked lesions at slaughter. Similar findings were recorded also in the serum Hp concentrations. For the concentrations of SAA, although the values recorded in pigs with clinical diseases were significantly higher than in apparently healthy pigs, the differences between pigs with gross lesions and without gross lesions were not significant. In addition, the serum CRP concentrations were significantly higher in pigs showing lesions in the lungs and one or more other organs compared to pigs showing lesions only in the lungs. Thus, the results presented by Pallarés et al. [139] indicate that the serum concentrations of CRP, SAA, 
as well as Hp can be used as markers of clinical diseases in pigs. These findings agree with those of Chen et al. [140], in which serum Hp and CRP concentrations were significantly higher in culled pigs than in clinically healthy pigs. However, according to Pallarés et al. [139], only Hp and CRP could be used as markers of the presence of lesions at slaughter, since they appear to differentiate apparently healthy pigs with lesions from pigs with no lesions. The presence of elevated serum Hpand CRP concentrations in apparently healthy pigs atslaughtercould provide important information to a veterinary inspector about the presence of sub-clinical lesions that could lead to condemnations or a decrease in the quality of carcasses.

\section{Conclusion}

The objective determination of animal health is important due to the increasing focus of consumers and farmers on the welfare of animals. As non-specific markers of inflammation, acute phase protein testing is a useful tool for the assessment of health in general, to monitor the health state, the spread of infection or the efficacy of treatment. The measurement of acute phase proteins may also be useful in defining the objective health status of an animal or a herd. They are reliablebiomarkers that can beused both in diagnostic approaches and for research purposes.

Practical uses and advantages of acute phase protein assays have been described in a large number of scientific reports published in the last few years. Clinical application of acute phase proteins has not been extensive in routine clinical animal practice due to practical limitations associated with their analysis. The most of the methods available for measuring specific acute phase proteins are immunological methods, which are time-consuming and relatively expensive, so limiting the wide-scale use of acute phase proteins in routine practice. Seeing that there is a broad spectrum of possible applications of acute phase protein based diagnostics for the use in ruminants and swine, it is necessary to develop and optimise rapid field tests that allow the determination of acute phase proteins in a short time period.

Despite the challenges in the determination of acute phase proteins, with the insights provided by ongoing research in this area, it is likely that these analytes will be increasingly used in the diagnosis and prognosis of diseases also in farm animal medicine. Acute phase proteins have proven to be very useful in the early detection of sub-clinical diseases or alterations of the health status of an animal, with predictive information regarding the development of disease. Changes in the serum concentrations of acute phase proteins indicate the need for a more detailed clinical evaluation of a patient. In addition, acute phase proteins can be a powerful tool in the monitoring of treatment.

\section{Acknowledgements}

This work was supported by VEGA Scientific Grants No 1/0592/12 and 1/0812/12 from the Ministry of Education, and by Slovak Research and Development Agency under contract No. APVV-0475-10. 


\section{Author details}

Csilla Tóthová, Oskar Nagy and Gabriel Kováč

*Address all correspondence to: tothova@uvm.sk

Clinic for Ruminants, University of Veterinary Medicine and Pharmacy, Košice, Slovak Republic

\section{References}

[1] Murata H., Shimada N., Yoshioka M. Current research on acute phase proteins in veterinary diagnosis: an overview. The Veterinary Journal 2004; 168: 28-40.

[2] Baumann H., Gauldie J. The acute phase response. Immunology Today 1994; 15: 74-80.

[3] Johnson HL., Chiou CC., Cho CT. Applications of acute phase reactants in infectious diseases. Journal of Microbiology, Immunology, Infection 1999; 32: 73-82.

[4] Whicher T., Bienvenu J., Price CP. Molecular biology, measurement and clinical utility of the acute phase proteins. Pure and Applied Chemistry 1991; 63 (8): 1111-1116.

[5] Endre ZH., Westhuyzen J. Early detection of acute kidney injury: emerging new biomarkers. Nephrology (Carlton) 2008; 13: 91-98.

[6] Cray C., Zaias J., Altman NH. Acute phase response in animals: a review. Comparative Medicine 2009; 59 (6): 517-526.

[7] Fearon DT., Locksley RM. The instructive role of innate imunity in the acquired immune response. Science 1996; 272: 50-54.

[8] Janeway CA., Travers P., Walport M., Schlomschik MJ. Immunobiology. 5th ed., London: Taylor \& Francis; 2001.

[9] Bochsler PN., Slauson DO. Inflammation and repair of tissue. In: Bochcler PN:, Slauson DO. (eds.). Mechanism of disease. A textbook of comparative general pathology. 3rd ed., St. Louis: Mosby; 2002. p140-245.

[10] Moshage H. Cytokines and the hepatic acute phase response. Journal of Pathology 1997; 181: 257-266.

[11] Gabay C., Kushner I. Acute-phase proteins and other systemic responses to inflammation. New England Journal of Medicine 1999; 340: 448-454.

[12] Gruys E., Toussaint MJM., Niewold TA., Koopmans SJ. Acute phase reaction and acute phase proteins. Journal of Zhejiang University Science 2005; 6B (11): 1045-1056. 
[13] Pyörälä S. Hirvonen's thesis on acute phase response in dairy cattle. PhD thesis. University of Helsinki, Helsinki, Finnland, ISBN 951-45-9104-6; 2000.

[14] Raynes JG. The acute phase response. Biochemical Society Transactions 1994; 22: 69-74.

[15] Petersen HH., Nielsen JP., Heegaard PMH. Application of acute phase protein measurements in veterinary clinical chemistry. Veterinary Research 2004; 35: 136-187.

[16] Cerón JJ., Eckersall PD., Martinez-Subiela S. Acute phase proteins in dogs and cats: current knowledge and future perspectives. Veterinary Clinical Pathology 2005; 34: 85-99.

[17] Niewold TA., Toussaint MJM., Gruys E. Monitoring health by acute phase proteins. Proceedings of the Fourth European Colloquium on Acute Phase Proteins. Segovia, Spain; 2003, p57-67.

[18] Horadagoda NU., Knox KM., Gibbs HA., Reid SW., Horadagoda A., Edwards SE., Eckersall PD. Acute phase proteins in cattle: Discrimination between acute and chronic inflammation. Veterinary Record 1999; 144: 437-441.

[19] Ceciliani F., Giordano A., Spagnolo V. The systemic reaction during inflammation: the acute phase proteins. Protein and Peptide Letters 2002; 9: 211-223.

[20] Wagener FA., Eggernt A., Boerman OC., Oyen WJ., Verhofstad A., Abraham NG., Adema G., van Kooyk Y., de Witte T., Figdor CG. Heme is a potent inducer of inflammation in mice and is countected by heme oxygenase. Blood 2002; 98: 1802-1811.

[21] Rossbacher J., Wagner L., Pasternack MS. Inhibitory effect of haptoglobin on granulocyte chemotaxis, phagocytosis and bactericidal activity. Scandinavian Journal of Immunology 1999; 50: 399-404.

[22] Eckersall PD., Bell R. Acute phase proteins: Biomarkers of infection and inflammation in veterinary medicine. The Veterinary Journal 2010; 185: 23-27.

[23] Lampreave F., Gonzalez-Ramon N., Martinez-Ayensa S., Hernandez M-A., Lorenzo H-K., Garcia-Gil A., Pineiro A. Characterisation of the acute phase serum protein response in pigs. Electrophoresis 1994; 15: 672-676.

[24] Kent J. Acute phase proteins: their use in veterinary diagnosis. British Veterinary Journal 1992; 148: 279-281.

[25] Heegaard PMH., Godson DL., Toussaint MJM., Tjornehoj K., Larsen LE., Viuff B., Ronsholt L. The acute phase response of haptoglobin and serum amyloid A (SAA) in cattle undergoing experimental infection with bovine respiratory syncytial virus. Veterinary Immunology and Immunopathology 2000; 77: 151-159.

[26] Bittrich S., Philipona C., Hammon HM., Romé V., Guilloteau P., Blum JW. Preterm as compared with full-term neonatal calves are characterized by morphological and 
functional immaturity of the small intestine. Journal of Dairy Science 2004; 87: 1786-1795.

[27] Odle J. New insights into the utilization of medium-chain triglycerides by the neonate: observation from a piglet model. Journal of Nutrition 1997; 127: 1061-1067.

[28] Orro T., Jacobsen S., LePage J-P., Niewold T., Alasuutari S., Soveri T. Temporal changes in serum concentrations of acute phase proteins in newborn dairy calves. The Veterinary Journal 2008; 176: 182-187.

[29] Morein B., Abusugra I., Blomquist G. Immunity in neonates. Veterinary Immunology and Immunopathology 2002; 87: 207-213.

[30] Yamanaka H., Hagiwara K., Kirisawa R., Iwai H. Transient detection of proinflammatory cytokines in sera of colostrum-fed newborn calves. Journal of Veterinary Medical Science 2003; 65: 813-816.

[31] Schroedl W., Jaekel L., Krueger M. C-reactive protein and antibacterial activity in blood plasma of colostrum-fed calves and the effect of lactulose. Journal of Dairy Science 2003; 86: 3313-3320.

[32] McDonald TL., Larson MA., Mack DR., Weber A. Elevated extrahepatic expression and secretion of mammary-associated serum amyloid A 3 (M-SAA3) into colostrum. Veterinary Immunology and Immunopathology 2001; 83: 203-211.

[33] Dobryszycka W. Biological functions of haptoglobin, new pieces to an old puzzle. European Journal of Clinical Chemistry and Clinical Biochemistry 1997; 35: 647-654.

[34] Tóthová Cs., Nagy O., Seidel H., Kováč G. Age-related changes in the concentrations of acute phase proteins and some variables of protein metabolism in calves. Wiener Tierärztliche Monatschrift - Veterinary Medicine Austria 2011; 98: 33-44.

[35] Alsemgeest SPM., Jonker FH., Taverne MAM., Kalsbeek HC., Wensing T., Gruys E. Serum amyloid A and haptoglobin plasma concentrations in newborn calves. Theriogenology 1995; 43: 381-387.

[36] Hyvönen P., Suojala L., Orro T., Haaranen J., Simola O., Rontved C., Pyörälä S. Transgenic cows that produce recombinant human lactoferrin in milk are not protected from experimental Escherichia coli intramammary infection. Infection and Immunity 2006; 74: 6206-6212.

[37] Knowles TG., Edwards JE., Bazeley KJ., Brown SN., Butterworth A., Warriss PD. Changes in the blood biochemical and haematological profile in neonatal calves with age. Veterinary Record 2000; 18: 593-598.

[38] Gentry PA., Ross ML., Hayatgheybi H. Competency of blood coagulation in the newborn calf. Research in Veterinary Science 1994; 57: 336-342. 
[39] Morimatsu M., Syuto B., Shimada N., Fujinaga T., Yamamoto S., Saito M., Naiki M. Isolation and characterisation of bovine haptoglobin from acute phase sera. Journal of Biological Chemistry 1991; 266: 11833-11837.

[40] Godson DL., Campos M., Attah-Poku SK., Redmond MJ., Cordeiro DM., Sethi MS., Harland RJ., Babiuk LA. Serum haptoglobin as an indicator of the acute phase response in bovine respiratory disease. Veterinary Immunology and Immunopathology 1996; 51: 277-302.

[41] Yang FM., Haile DJ., Berger FG., Herbert DC., Van Beveren E., Ghio AJ. Haptoglobin reduces lung injury associated with exposure to blood. American Journal of Physiology and Lung Cell Molecular Physiology 2003; 284: L402-L409.

[42] Eckersall PD. Measurement of acute phase proteins as biomarkers of disease in production animals. Proceedings of the 57th Annual Meeting of the American College of Veterinary Pathologists and the 41st Annual Meeting of the American Society for Veterinary Clinical Pathology, 2-6 December 2006, Tucson, Arizona, USA; 2006. www.ivis.org (accessed March 2008)

[43] Makimura S., Suzuki N. Quantitative determination of bovine serum haptoglobin and its elevation in some inflammatory diseases. Japanese Journal of Veterinary Science 1982; 44: 15-21.

[44] Eckersall PD., Duthie S., Safi S., Moffatt D., Horadagoda NU., Doyle S, Parton R., Bennett D., Fitzpatrick JL. An automated biochemical assay for haptoglobin: Prevention of interference from albumin. Comparative Haematology International 1999; 5: 117-124.

[45] Weidmeyer CE., Solter PF. Validation of human haptoglobin immunoturbidimetric detection of haptoglobin in equine and canine serum and plasma. Veterinary Clinical Pathology 1996; 25: 141-146.

[46] Jensen LE., Whitehead AS. Regulation of serum amyloid A protein expression during the acute phase response. Biochemical Journal 1998; 334: 489-503.

[47] Weber A., Weber AT., McDonald TL., Larson MA. Staphylococcus aureus lipotechoic acid induces differential expression of bovine serum amyloid A3 (SAA3) by mammary epithelial cells: Implications of early diagnosis of mastitis. Veterinary Immunology and Immunopathology 2006; 109: 79-83.

[48] Mack DR., McDonald TL., Larson MA., Wei S., Weber A. The conserved TFLK motif of mammary-associated serum amyloid $\mathrm{A}$ is responsible for up-regulation of intestinal MUC3 mucin expression in vitro. Pediatric Research 2003; 53: 137-142.

[49] Yamamoto S., Miyadi S., Ashida Y. Preparartion of anti-canine serum amyloid A (SAA) serum and purification of SAA from canine high-density lipoprotein. Veterinary Immunology and Immunopathology 1994; 41: 41-53.

[50] Stoneham SJ., Palmer L., Cash R., Rossdale PD. Measurement of serum amyloid A in the neonatal foal using a latex agglutination immunoturbidimetric assay: determina- 
tion of the normal range, variation with age and response to disease. Equine Veterinary Journal 2001; 33: 599-603.

[51] Hirvonen J., Pyörälä S. Acute phase response in dairy cows with surgically-treated abdominal disorders. The Veterinary Journal 1998; 155: 53-61.

[52] Gentry PA. Acute phase proteins. In: Loeb WF., Quimby FW. (eds.). Clinical chemistry of laboratory animals. Philadelphia: Taylor \& Francis; 1999. p336-398.

[53] Thomas JS. Overview of plasma proteins. In: Feldman BF., Zinkl JG., Jain NC. (eds.). Schalm's Veterinary Hematology. Philadelphia: Lippincott Williams \& Wilkins; 2000. p891-898.

[54] Rubel C., Fernandez GC., Dran G., Bompadre MB., Isturiz MA., Palermo MS. Fibrinogen promotes neutrophil activation and delays apoptosis. Journal of Immunology 2001; 166: 2002-2010.

[55] Aldred AR., Schreiber G. The negative acute phase protein. In: Mackiewicz I., Kushner I., Baumann H. (Eds.). Acute phase proteins. Molecular biology, biochemistry, and clinical applications. Boca Raton, Florida: CRC Press; 1993. p21-37.

[56] Mackiewicz A. Acute phase proteins and transformed cells. International Review of Cytology 1997; 170: 225-300.

[57] Stokol T., Tarrant JM., Scarlett JM. Overestimation of canine albumin concentration with the bromcresol-green method in heparinized plasma samples. Veterinary Clinical Pathology 2001; 30: 170-178.

[58] Pepys MB., Hirschfield GM. C-reactive protein: a critical update. Journal of Clinical Investigation; 111: 1805-1812.

[59] Mold C., Rodriguez W., Rodic-Polic B., Du Clos TW. C-reactive protein mediates protection from lipopolysaccharide through interactions with Fc-gammaR. Journal of Immunology 2002; 169: 7019-7025.

[60] Eckersall PD., Conner JG., Harvie J. An immunoturbidimetric assay for canine C-reactive protein. Veterinary Research Communications 1991; 15: 17-24.

[61] Yamamoto S., Shida T., Miyadi S., Santsuka H., Fujise H., Mukawa K., Furukawa E., Nagae T., Naiki M. Changes in serum C-reactive protein levels in dogs with various disorders and surgical trauma. Veterinary Research Communications 1993; 17: 85-93.

[62] Fournier T., Najet Medjoubi N., Porquet D. Alpha-1-acid glycoprotein: review. Biochimica et Biophysica Acta 2000; 1482: 157-171.

[63] Israili ZH., Dayton PG. Human Alpha-1-Glycoprotein and its interactions with drugs. Drug Metabolites Revue 2001; 33: 161-235. 
[64] Tamura K., Yatsu T., Itoh H., Motoi Y. Isolation, characterization and quantitative measurement of serum a1-acid glycoprotein in cattle. Japanese Journal of Veterinary Science 1989; 51: 987-994.

[65] Segales J., Pineiro C., Lampreave F., Nofrarias M., Mateu E., Calsamiglia M., Andres J., Morales M., Pineiro M., Domingo M. Haptoglobin and pig-major acute protein are increased in pigs with postweaning multisystemic wasting syndrome (PMWS). Veterinary Research 2004; 35: 275-282.

[66] Snowder GD., van Vleck LD., Cundiff LV., Bennett GL. Bovine respiratory disease in feedlot cattle: Environmental, genetic, and economic factors. Journal of Animal Science 2006; 84: 1999-2008.

[67] Gänheim C., Hultén C., Carlsson U., Kindahl H., Niskanen R., Persson Waller K. The acute phase response in calves experimentally infected with bovine viral dirrhoea virus and/or Mannheimia haemolytica. Veterinary Medicine B 2003; 50: 1-8.

[68] Sivula NJ., Ames TR., Marsh WE., Werdin RE. Descriptive epidemiology of morbidity and mortality in Minnesota dairy heifer calves. Preventive Veterinary Medicine 1996; 27 (3-4): 155-171.

[69] Conner JG., Eckersall PD., Wiseman A., Bain RK., Douglas TA. Acute phase response in calves following infection with Pasteurella haemolytica, Ostertagia ostertagi and endotoxin administration. Research in Veterinary Science 1989; 47 (2): 203-207.

[70] Horadagoda NU., Eckersall PD. Immediate response in TNF- $\alpha$ and acute phase protein concentrations to infection with Pasteurella haemolytica A1 in calves. Research in Veterinary Science 1994; 57 (1): 129-132.

[71] Angen Ø., Thomsen J., Larsen LE., Larsen J., Kokotovic B., Heegaard PMH., Enemark JMD. Respiratory disease in calves: Microbiological investigations on trans-tracheally aspirated bronchoalveolar fluid and acute phase protein response. Veterinary Microbiology 2009; 137: 165-171.

[72] Tóthová Cs., Nagy O., Seidel H., Kováč G. The effect of chronic respiratory diseases on acute phase proteins and selected blood parameters of protein metabolism in calves. Berliner und Münchener Tierärztliche Wochenschrift 2010; 123 (7/8): 307-313.

[73] Dowling A., Hodgson JC., Schock A., Donachie W., Eckersall PD., McKendrick IJ. Experimental induction of pneumonic pasteurellosis in calves by intratracheal infection with Pasteurella multocida biotype A:3. Research in Veterinary Science 2002; 73: 37-44.

[74] Grell NS., Tjørnehøj K., Larsen LE., Heegaard PMH. Marked induction of IL-6, haptoglobin and INF- $\gamma$ following experimental BRSV infection in young calves. Veterinary Immunology and Immunopathology 2005; 103 (3-4): 235-245.

[75] Nikunen S., Härtel H., Orro T., Neuvonen E., Tanskanen R., Kivelä S-L., Sankari S., Aho P., Pyörälä S., Saloniemi H., Soveri T. Association of bovine respiratory disease 
with clinical status and acute phase proteins in calves. Comparative Immunology, Microbiology \& Infectious Diseases 2007; 30: 143-151.

[76] Svensson C., Liberg P., Hultgren J. Evaluating the efficacy of serum haptoglobin concentration as indicator of respiratory-tract disease in dairy calves. The Veterinary Journal 2007; 174 (2): 288-294.

[77] Carter JN., Meredith GL., Montelongo M., Gill DR., Krehbiel CR., Payton ME., Confer AW. Relationship of vitamin E supplementation and antimicrobial treatment with acute-phase protein responses in cattle affected by naturally acquired respiratory tract disease. American Journal of Veterinary Research 2002; 63: 1111-1117.

[78] Berry BA., Confer AW., Krehbiel CR., Gill DR., Smith RA., Montelongo M. Effects of dietary energy and starch concentrations for newly received feedlot calves: II. Acutephase protein response. Journal of Animal Science 2004; 82: 845-850.

[79] Humblet M-F., Coghe J., Lekeux P., Godeau J-M. Acute phase proteins assessment for an early selection of treatments in growing calves suffering from bronchopneumonia under field conditions. Research in Veterinary Science 2004; 77: 41-47.

[80] Jawor P., Stefaniak T. Acute phase proteins in treatment of calves with respiratory tract inflammation. Folia Universitatis Agriculturae Stetinensis, Zootechnica 2006; 48 (250): 51-56.

[81] Skinner JG., Brown RAL., Roberts L. Bovine haptoglobin response in clinically defined field conditions. Veterinary Record 1991; 128: 147-149.

[82] Svensson C., Lundborg K., Emanuelson U., Olsson SO. Morbidity in Swedish dairy calves from birth to 90 days of age and individual calf-level risk factors for infectious diseases. Preventive Veterinary Medicine 2003; 58 (3/4): 179-197.

[83] Piercy DWT. Acute phase responses to experimental salmonellosis in calves and colibacillosis in chicken: serum iron and caeruloplasmin. Journal of Comparative Pathology 1979; 89 (3): 309-319.

[84] Deignan T., Alwan A., Kelly J., McNair J., Warrens T., O'Farrelli C. Serum haptoglobin: an objective indicator of experimentally-induced Salmonella infection in calves. Research in Veterinary Science 2000; 69: 153-158.

[85] Jawor P. Determination of haptoglobin and fibrinogen during monitoring herd health and selected inflammatory states in cattle. PhD thesis. Wroclaw University of Environmental and Life Sciences; 2007.

[86] Tóthová Cs., Nagy O., Seidel H., Kováč G. Acute phase proteins in relation to various inflammatory diseases of calves. Comparative Clinical Pathology 2011, DOI 10.1007/ s00580-011-1224-5.

[87] Muller-Doblies D., Arquint A., Schaller P., Heegaard PMH., Hilbe M., Albini S., Abril C., Tobler K., Ehrensperger F., Peterhans E., Ackermann M., Metzler A. Innate immune responses of calves during transient infection with a noncytopathic strain of 
bovine viral diarrhoea virus. Clinical and Diagnostic Laboratory Immunology 2004; 11: 302-312.

[88] Werling D., Sutter F., Arnold M., Kun G., Tooten PC., Gruys E., Kreuzer M., Langhans W. Characterisation of the acute phase response of heifers to a prolonged low dose infusion of lipopolysaccharide. Research in Veterinary Science 1996; 61: 252-257.

[89] Gänheim C., Alenius S., Persson Waller K. Acute phase proteins as indicators of calf herd health. The Veterinary Journal 2007; 173: 645-651.

[90] Bradley AJ. Bovine mastitis: an evolving disease. The Veterinary Journal 2002; 164: 116-128.

[91] Sandholm M., Honkanen-Buzalski T., Kaartinen L., Pyörälä S. The bovine udder and mastitis. Jyväskylä, Finnland: Gummerus Kirjapaino Oy; 1995, p312.

[92] Gerardi G., Bernardini D., Elia CA., Ferrari V., Iob L., Segato S. Use of serum amyloid A and milk amyloid A in the diagnosis of subclinical mastitis in dairy cows. Journal of Dairy Research 2009; 76: 411-417.

[93] Conner JG., Eckersall PD., Doherty M., Douglas TA. Acute phase response and mastitis in the cow. Research in Veterinary Science 1986; 41 (1): 126-128.

[94] Hirvonen J., Pyörälä S., Jousimies-Somer H. Acute phase response in heifers with experimentally induced mastitis. Journal of Dairy Research 1996; 63 (3): 31-360.

[95] Hirvonen J., Eklund K., Teppo AM., Huszenicza G., Kulcsar M., Saloniemi H., Pyörälä S. Acute phase response in dairy cows with experimentally induced Escherichia coli mastitis. Acta Veterinaria Scandinavica 1999; 40: 35-46.

[96] Eckersall PD., Young FJ., McComb C., Hogarth CJ., Safi S., Weber A., McDonald T., Nolan AM., Fitzpatrick JL. Acute phase proteins in serum and milk from dairy cows with clinical mastitis. Veterinary Record 2001; 148: 35-41.

[97] Jacobsen S., Niewold TA., Kornalijnslijper E., Toussaint MJM., Gruys E. Kinetics of local and systemic isoforms of serum amyloid A in bovine mastitic milk. Veterinary Immunology and Immunopathology 2005; 104: 21-31.

[98] Pedersen LH., Aalbœk B., Røntved CM., Ingvartsen KL., Sørensen NS., Heegaard $\mathrm{PMH}$., Jensen HE. Early pathogenesis and inflammatory response in experimental bovine mastitis due to Streptococcus uberis. Journal of Comparative Pathology 2003; 128: $156-164$.

[99] Nielsen BH., Jacobsen S., Andersen PH., Niewold TA., Heegaard PMH. Acute phase protein concentrations in serum and milk from healthy cows, cows with clinical mastitis and cows with extramammary inflammatory conditions. The Veterinary Record 2004; 154: 361-365. 
[100] Grönlund U., Sandgren CH., Persson Waller K. Haptoglobin and serum amyloid A in milk from dairy cows with chronic sub-clinical mastitis. Veterinary Research 2005; 36: 191-198.

[101] Kováč G., Tóthová Cs., Nagy O., Seidel H. Milk amyloid A and selected serum proteins in cows suffering from mastitis. Acta Veterinaria Brno 2011; 80: 3-9.

[102] Petersen HH., Gardner IA., Rossitto P., Larsen HD., Heegaard PMH. Accuracy of milk amyloid A (MAA) concentration and somatic cell count for diagnosing bovine mastitis. In: Proceedings of the 5th International Colloquium on Animal Acute Phase Proteins. 14-15 March 2005, Dublin, Ireland; 2005, p43-44.

[103] Nazifi S., Khoshvaghti A., Gheisari HR. Evaluation of serum and milk amyloid A in some inflammatory diseases of cattle. Iranian Journal of Veterinary Research 2008; 9: 222-226.

[104] Lippolis JD. Immunological signaling networks: integrating the body's immune response. Journal of Animal Sciences 2008; 86: E53-E63.

[105] Krakowski L., Zdzisińska B. Selected cytokines and acute phase proteins in heifers during the ovarian cycle course and in different pregnancy periods. Bulletin of the Veterinary Institue Pulawy 2007; 51: 31-36.

[106] Saini PK., Riaz M., Webert DW., Eckersall PD., Young CR., Stanker LH., Chakrabarti E., Judkins JC. Development of a simple enzyme immunoassay for blood haptoglobin concentration in cattle and its application in improving food safety. American Journal of Veterinary Research 1998; 59: 1101-1107.

[107] Gymnich S., Hiss S., Sauerwein H., Petersen B. Haptoglobin in sows at parturition. In: Proceedings of the Fourth European Colloquium on Acute Phase Proteins. Segovia, Spain; 2003, p136.

[108] Uchida E., Katoh N., Takahashi K. Appearance of haptoglobin in serum from cows at parturition. Journal of Veterinary Medical Science 1993; 55: 893-894.

[109] Ametaj B. A new understanding of the causes of fatty liver in dairy cows. Advances in Dairy Technology 2005; 17: 97-112.

[110] Tóthová Cs., Nagy O., Seidel H., Konvičná J., Farkašová Z., Kováč G. Acute phase proteins and variables of protein metabolism in dairy cows during the pre- and postpartal period. Acta Veterinaria Brno 2008; 77: 51-57.

[111] Chan JPW., Chang C-C., Hsu W-I., Liu W-B., Chen T-H. Association of increased serum acute-phase protein concentrations with reproductive performance in dairy cows with postpartum metritis. Veterinary Clinical Pathology 2010; 39 (1): 72-78.

[112] Alsemgeest SPM., Taverne MAM., Boosman R., van der Weyden BC., Gruys E. Peripartum acute-phase protein SAA concentration in plasma of cows and foetuses. American Journal of Veterinary Research 1993; 54: 164-167. 
[113] Regassa F., Noakes DE. Acute phase protein response of ewes and the release of PGFM in relation to uterine involution and the presence of intrauterine bacteria. Veterinary Record 1999; 144: 502-506.

[114] Young CR., Eckersall PD., Saini PK., Stanker L. Validation of immunoassays for bovine haptoglobin. Veterinary Immunology and Immunopathology 1995; 49: 1-13.

[115] Alsemgeest SPM., vant Clooster GAE., van Miert ASJPAM., Huslkamp-Koch CK., Gruys E. Primary bovine hepatocytes in the study of cytokine induced acute-phase protein secretion in vitro. Veterinary Immunology and Immunopathology 1996; 53: 179-184.

[116] Chan JPW., Chu CC., Fung HP., Chuang ST., Lin YC., Chu RM., Lee SL. Serum haptoglobin concentration in cattle. Journal of Veterinary Medical Science 2004; 66: 43-46.

[117] Smith BI., Donovan GA., Risco CA., Young CR., Stanker LR. Serum haptoglobin concentrations in Holstein dairy cattle with toxic puerperal metritis. The Veterinary Record 1998; 142 (4): 83-85.

[118] Hirvonen J., Huszenicza G., Kulcsar M., Pyörälä S. Acute-phase response in dairy cows with acute postpartum metritis. Theriogenology 1999; 51 (6): 1071-1083.

[119] Huzzey JM., Duffield TF., LaBlanc SJ., Veira DM., Weary DM., Keyserlingk MAG. Haptoglobin as an early indicator of metritis. Journal of Dairy Science 2009; 92 (2): 621-625.

[120] Dubuc J., Duffield TF., Leslie KE., Walton JS., LeBlanc SJ. Risk factors for postpartum uterine diseases in dairy cows. Journal of Dairy Science 2010; 93 (12): 5764-5771.

[121] Mordak R. Usefulness of haptoglobin for monitoring the efficiency of therapy of fetal membrane retention in cows. Medycyna Weterynaryjna 2008; 64 (4A): 434-437.

[122] Warnick LD., Janssen D., Guard CL., Grohn YT. The effect of lameness on milk production in dairy cows. Journal of Dairy Science 2001; 84: 1988-1997.

[123] Stokka GL., Lechtenberg K., Edwards T., MacGregor S., Voss K., Griffin D., Grotelueschen DM., Smith RA., Perino LJ. Lameness in feedlot cattle. Veterinary Clinics of North America: Food Animal Practice 2001; 17: 189-207.

[124] Kujala M., Orro T., Soveri T. Serum acute phase proteins as a marker of inflammation in dairy cattle with hoof diseases. Veterinary Record 2010; 166: 240-241.

[125] Tóthová Cs., Nagy O., Seidel H., Paulíková I., Kováč G. The influence of hoof diseases on the concentrations of some acute phase proteins and other variables of the protein profile in heifers. Acta Veterinaria (Beograd) 2011; 61: 141-150.

[126] Laven RA., Livesey CT., May SA. Relationship between acute phase proteins and hoof horn haemorrhages in postpartum first-lactation heifers. Veterinary Record 2004; 154: 135-138. 
[127] Smith BI., Kauffold J., Sherman L. Serum haptoglobin concentrations in dairy cattle with lameness due to claw disorders. The Veterinary Journal 2010; 186 (2): 162-165.

[128] Jawor P., Steiner S., Stefaniak T., Baumgartner W., Rzasa A. Determination of selected acute phase proteins during the treatment of limb diseases in dairy cows. Veterinary Medicine - Czech 2008; 53: 173-183.

[129] Jafarzadeh SR., Nowrouzian I., Khaki Z., Ghamsari SM., Adibhashemi F. The sensitivities and specificities of total plasma protein and plasma fibrinogen for the diagnosis of traumatic reticuloperitonitis in cattle. Preventive Veterinary Medicine 2004; 65: $1-7$.

[130] McSherry BJ., Horney FD., deGroot JJ. Plasma fibrinogen levels in normal and sick cows. Canadian Journal of Comparative Medicine 1970; 34 (3): 191-197.

[131] Jawor P., Stefaniak T., Steiner S., Baumgartner W. Dynamics of selected acute phase proteins in surgical abomasal reposition in cows. Folia Veterinaria 2009; 53 (Suppl. LIII): 18-21.

[132] Nazifi S., Rezakhani A., Moaddeli A., Zarifi M., Gheisari HR. Study on diagnostic values of haptoglobin and serum amyloid A concentration in bovine heart diseases. Comparative Clinical Pathology 2009; 18: 47-51.

[133] Harding JC., Baarsch MJ., Murtaugh MP. Association of Tumor Necrosis Factor and acute phase reactant changes with post arrival disease in swine. Journal of Veterinary Medicine Series B 1997; 44: 405-413.

[134] Eurell TE., Bane DP., Hall WF., Schaeffer DJ. Srum haptoglobin concentration as an indicator of weight gain in pigs. Canadian Journal of Veterinary Research 1992; 56 : 6-9.

[135] Lauritzen B., Lykkesfeldt J., Skaanild MT., Angen Ø., Nielsen JP., Friis C. Putative biomarkers for evaluating antibiotic treatment of Actinobacillus pleuropneumoniae infection in pigs. Research in Veterinary Science 2003; 74: 271-277.

[136] Sorensen NS., Tegtmeier C., Andresen LO., Piňeiro M., Toussaint MJM., Campbell FM., Lampreave F., Heegaard PMH. The porcine acute phase protein response to acute clinical and subclinical experimental infection with Streptococcus suis. Veterinary Immunology and Immunopathology 2006; 113: 157-168.

[137] Francisco CJ., Shyrock TR., Bane DP., Unverzagt L. Serum haptoglobin concentration in growing swine after intranasal challenge with Bordetella bronchiseptica and toxigenic Pasteurella multocida type D. Canadian Journal of Veterinary Research 1996; 60: 222-227.

[138] Quereda JJ., Gómez S., Seva J., Ramis G., Cerón JJ., Muňoz A., Pallarés FJ. Acute phase proteins as a tool for differential diagnosis of wasting diseases in growing pigs. Veterinary Record 2012; 170 (21), doi: 10.1136/vr. 100005. 
[139] Pallarés FJ., Martinez-Subiela S., Seva J., Ramis G., Fuentes P., Bernabé A., Muňoz A., Cerón, JJ. Relationship between serum acute phase protein concentrations and lesions in finishing pigs. The Veterinary Journal 2008; 177: 369-373.

[140] Chen HH., Lin JH., Fung HP., Ho LL., Yang PC., Lee WC., Lee YP., Chu RM. Serum acute phase proteins and swine health status. The Canadian Journal of Veterinary Research 2003; 67: 283-290. 